\title{
Deficits in Oral Health Behavior and Oral Health Status in Patients after Lung Transplantation
}

\author{
Dissertation \\ zur Erlangung des akademischen Grades \\ Dr. med. dent. \\ an der medizinischen Fakultät \\ der Universität Leipzig
}

eingereicht von: Anna Marcinkowski

geboren am: $\quad$ 27. April 1988 in Essen

angefertigt an: Poliklinik für Zahnerhaltung und Parodontologie des

Universitätsklinikums Leipzig

Betreuer: $\quad$ PD Dr. med. dent. Dirk Ziebolz, M.Sc.

Beschluss über die Verleihung des Doktorgrades vom: 21.08.2018 


\section{Inhaltsverzeichnis}

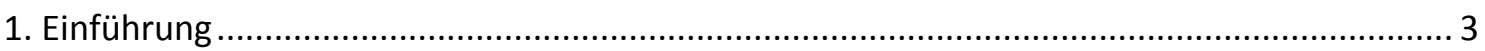

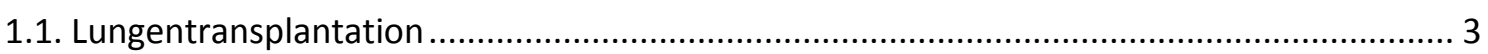

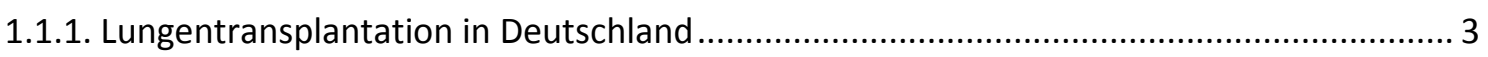

1.1.2. Grunderkrankungen und Indikationen zur Lungentransplantation .................................. 5

1.1.3. Komplikationen nach Lungentransplantation ............................................................ 7

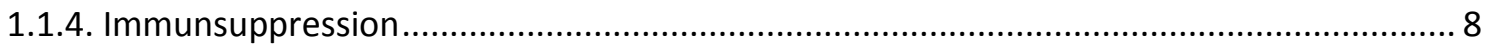

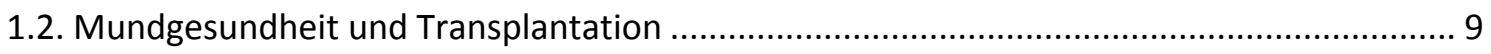

1.2.1. Zahnärztliche Sanierung vor und nach Transplantation ............................................. 9

1.2.2. Mundgesundheitsverhalten nach Transplantation ...................................................... 11

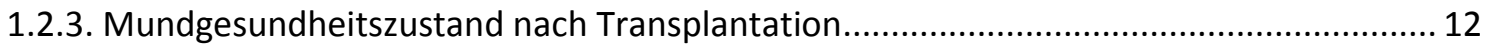

1.3. Zielsetzung und Fragestellung der vorliegenden Studie .................................................. 15

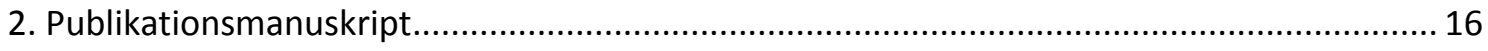

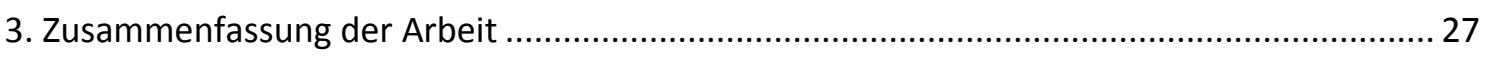

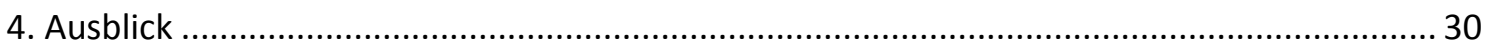

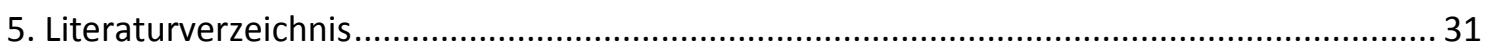

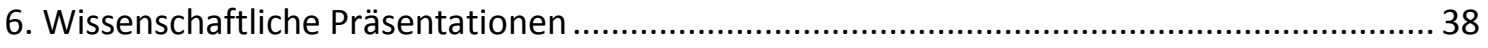

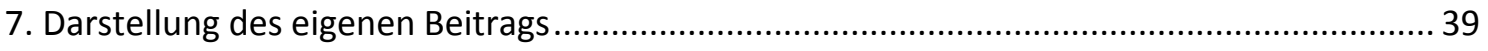

8. Erklärung über die eigenständige Abfassung der Arbeit......................................................... 41

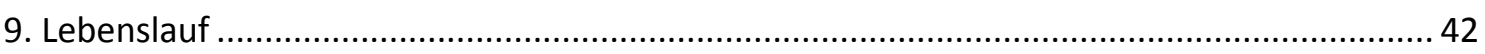

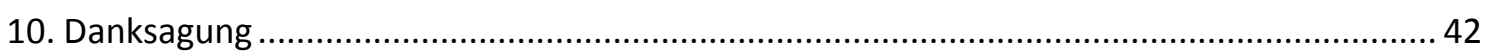




\section{Einführung}

Patienten nach einer Organtransplantation, wie z.B. einer Lungentransplantation (LuTx), zählen zu den Risikopatienten in der zahnärztlichen Praxis [30]. Aus diesem Grund ist eine frühzeitige Sanierung vor und eine konsequente Nachsorge nach einer Transplantation (Tx) wichtig [16]. Mit der Thematik zur Mundgesundheit und LuTx beschäftigte sich bisher nur eine Studie, die sich schwerpunktmäßig jedoch mit dem Mundgesundheitszustand vor LuTx befasste [52]. Vorliegende Studien anderer Gruppen von Tx-Patienten zeigen aber erhebliche Defizite in der Mundgesundheit mit einer hohen Karies- und Parodontitisprävalenz in dieser speziellen Klientel $[15,23,42,55]$. Über den Mundgesundheitszustand von Patienten nach LuTx liegen bisher keine Kenntnisse vor. Demnach ist die Untersuchung dieser Patientengruppe in Hinblick auf die Mundgesundheit wichtig.

\subsection{Lungentransplantation}

\subsubsection{Lungentransplantation in Deutschland}

Die LuTx ist nach Ausschöpfung aller konservativen Therapieverfahren eine bedeutende Behandlungsoption bei Lungenerkrankungen im Endstadium mit einer prognostizierten Lebenserwartung von 2-3 Jahren, wie z.B. chronisch obstruktive Lungenerkrankungen (chronic obstrutive pulmonary diseases: COPD), Mukoviszidose (cystic fibroses: CF), interstitielle Lungenerkrankungen (interstitial lung diseases: ILD) und a1AntitrypsinMangel (a1AT-Mangel) [54]. In Deutschland wurden 2016 nach Angaben der Eurotransplant International Foundation 328 LuTx durchgeführt, davon waren 281 Doppel-, 38 Einzel-Lungentransplantationen, 7 Herz-Lungentransplantationen und 2 Lungen- und Lebertransplantationen [13]. Insgesamt waren 2016 in Deutschland 390 Patienten auf der Warteliste für eine LuTx gelistet [12]. Abbildung 1 zeigt den Verlauf der Warteliste für LuTx und die Zahl der durchgeführten LuTx in Deutschland über die letzten 10 Jahre. 


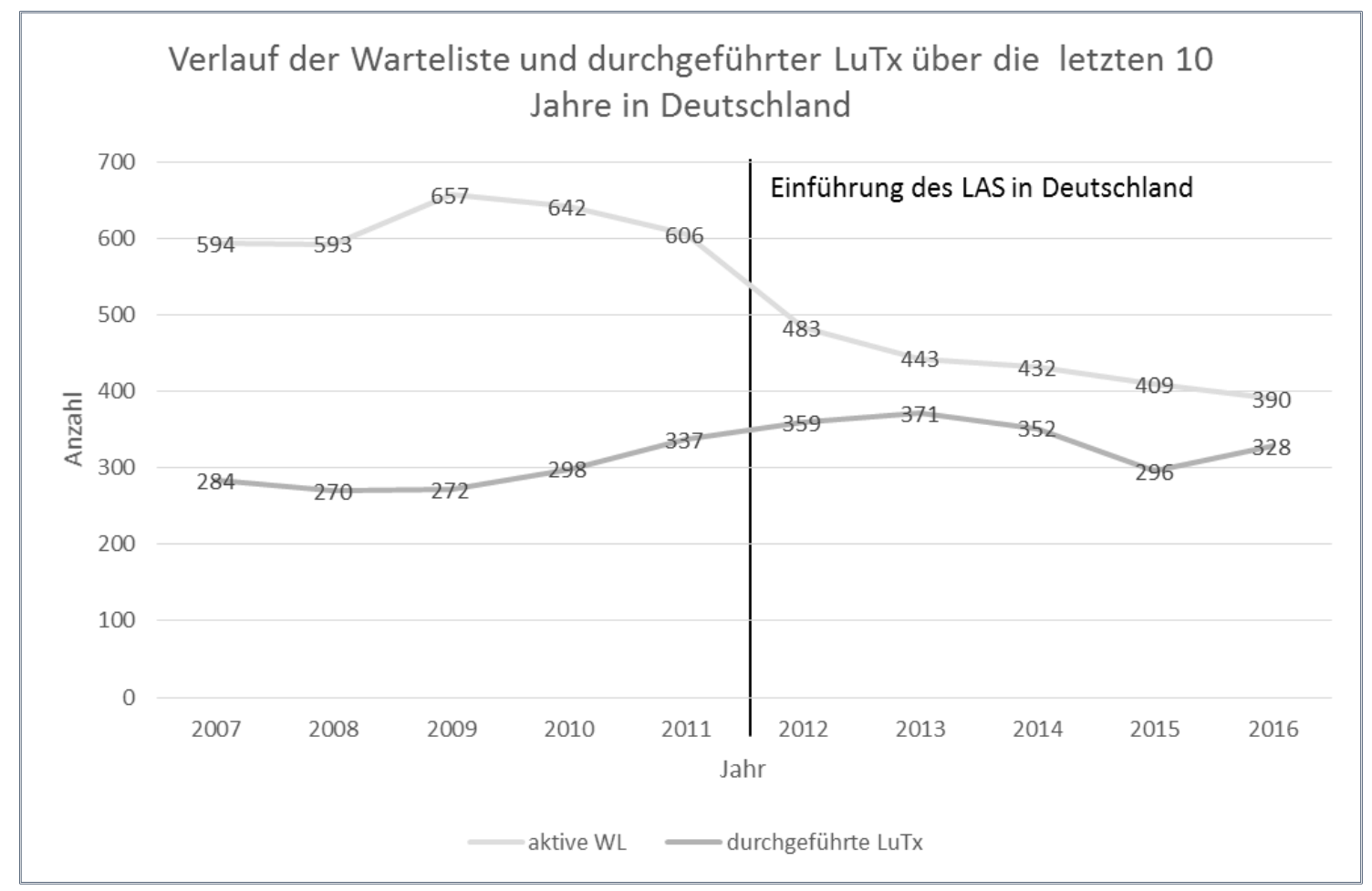

Abbildung 1: Verlauf der Warteliste (WL) und durchgeführter LuTx in Deutschland über die letzte 10 Jahre mit Einführung des Lung allocation score (LAS) Ende 2011 (Quelle: zugrundeliegende Zahlen wurden eurotransplant.org entnommen [12,13])

Der Lung allocation score (LAS) wurde 2005 in den USA als Verfahren eingeführt um einen potenziellen Transplantatempfänger für die Zuweisung einer Spenderlunge einzustufen; LAS wird seit Dezember 2011 auch in Deutschland angewendet [47]. Mit dem LAS sollen, unter Vernachlässigung der Wartezeit, Patienten mit hoher Dringlichkeit und guter postoperativer Überlebenswahrscheinlichkeit zeitnah transplantiert werden können. Zum LAS gehören 18 medizinische Parameter, wie z.B. Lungenfunktion, Blutgasanalyse und Sauerstoffbedarf, die regelmäßig aktualisiert werden müssen. Der LAS kann einen Punktwert von 0-100 annehmen. Bei einem niedrigen LAS (0-50) müssen die Untersuchungen alle 90 Tage erneuert werden, bei einem hohen LAS (>50) alle 14 Tage [3]. Das Ziel des LAS-Systems ist es die Wartelistensterblichkeit zu verringern und den Transplantationserfolg zu verbessern $[47,48]$. Nach Einführung des LAS in Deutschland (2011) wurde die aktive Warteliste um ca. 34\% reduziert [12] und die Wartelistensterblichkeit um $44 \%$ gesenkt [11]. 


\subsubsection{Grunderkrankungen und Indikationen zur Lungentransplantation}

Die Indikation zur LuTx besteht bei allen ursachenbezogenen Lungenerkrankungen (COPD, ILD, CF, a1AT-Mangel sowie seltene andere Erkrankungen; Abbildung 2), bei denen durch respiratorische Insuffizienz eine stark eingeschränkte Lebensqualität vorliegt. Dabei müssen sämtliche konservativen Therapien ausgeschöpft sein, die Zweijahresüberlebenswahrscheinlichkeit muss unter 50 \% liegen und ein Lebensalter von 65 Jahren darf nicht überschritten sein [47].

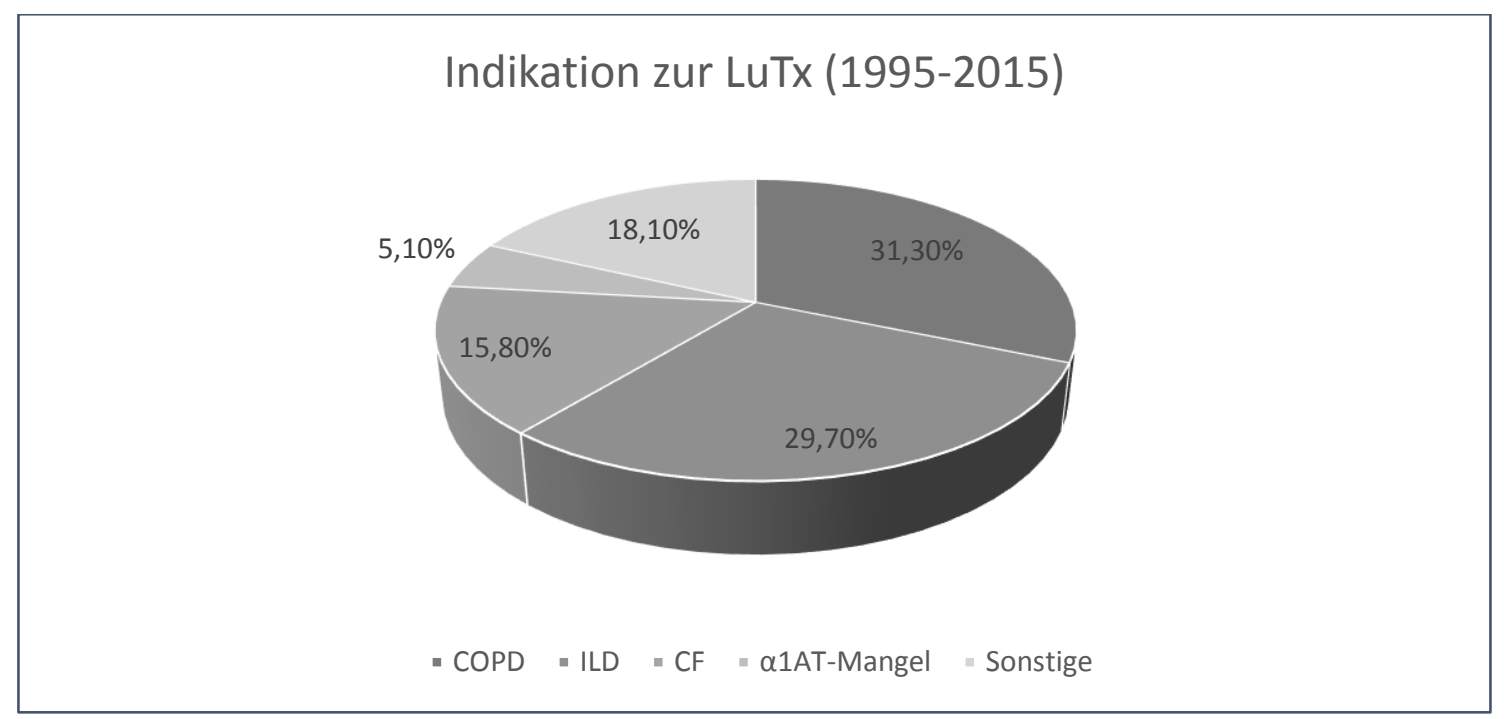

Abbildung 2: Verteilung der Indikationsgruppen zur LuTx (1995-2015) (Quelle: zugrundeliegende Zahlen wurden der International Society for Heart and Lung Transplantation / ISHLT entnommen [20])

Im Folgenden werden die in Abbildung 2 gezeigten Indikationen (LungenGrunderkrankungen) näher erläutert.

a) Chronisch obstruktive Lungenerkrankung: Die chronisch obstruktive Lungenerkrankung (COPD) ist mit 31,3 \% die häufigste Indikation zur Lungentransplantation [20]. Die Erkrankung betrifft größtenteils ältere Menschen und ist durch Husten, Auswurf und insbesondere durch (ausgeprägte) Luftnot gekennzeichnet. Als Hauptursache wird das Rauchen angegeben. Eine weitere Ursache ist die Exposition mit großen Mengen von Fremdpartikeln, wie z.B. Kohlenstaub. Dies kann zu einer Störung der bronchialen Reinigungsfähigkeit führen und resultiert in einer Entzündung und Zerstörung des Flimmerepithels in den Bronchien. Besteht keine Regeneration des Flimmerepithels folgt verstärkt Husten und Schleimproduktion als reinigende Ersatzfunktion. Der 
Krankheitsverlauf ist sehr unterschiedlich und kann über viele Jahre stabil bleiben. Daher haben diese Patienten beim LAS häufig lange einen geringen Punktwert. Mit zunehmendem Krankheitsverlauf kommt es zu Obstruktionen der Atemwege und Emphysemen mit steigender Luftnot [51].

b) Interstitielle Lungenerkrankungen: Die interstitiellen Lungenerkrankungen (ILD) umfassen eine heterogene Gruppe verschiedenster Lungenerkrankungen, die das Interstitium und die Alveolen betreffen. Der durchschnittliche Anteil zur LuTx liegt bei $29,7 \%$ [20]. Durch eine zunehmende Vernarbung der Lunge entsteht in einigen Fällen eine Lungenfibrose, wie u.a. die idiopathische Lungenfibrose. Die Ursachen sind mannigfaltig und oft nicht bekannt. Es wird ein Zusammenspiel von exogener Noxe und genetischer Prädisposition vermutet [7,51]. Bekannte Ursachen sind z.B. Nebenwirkungen von Medikamenten (z.B. Amiodaron oder Methotrexat) und die Mitbeteiligung der Lunge durch eine rheumatische Grunderkrankung.

c) Zystische Fibrose: Die zystische Fibrose (CF oder Mukoviszidose) ist die zweithäufigste genetisch bedingte Erkrankung in Mitteleuropa und trägt zu 15,8 \% der LuTx bei [20]. Ein Defekt auf dem Chromosom 7, das Informationen für Transportproteine enthält, ist die Ursache für die CF. Der Defekt betrifft das Cystic-Fibrosis-Transmembrane-Conductance-Regulator-Protein (CFTR-Protein) und führt schlussendlich zu einem visköseren Sekret [51]. Bei den CF-Patienten handelt es sich in Bezug auf das LuTx-Kollektiv um deutlich jüngere Patienten mit einer - in der Adoleszenz - teilweise schlechten Compliance [5]. Durch das visköse Sekret liegt eine starke bakterielle Besiedelung der Lunge vor, die nachfolgend häufig eine Antibiotikatherapie bei diesen Patienten erforderlich macht [28].

d) $\alpha 1$-Antitrypsinmangel: Der a1-Antitrypsinmangel macht mit 5,1 \% eine eher kleine Indikationsgruppe zur LuTx aus [20]. Als eine autosomal rezessiv vererbte Erkrankung entwickelt sie sich als Lungenemphysem durch Destruktion der Alveolen und teilweise als chronische Hepatitis in der Leber. $\alpha 1$-Antitrypsin ist die wichtigste Antiprotease und kommt verstärkt in der Lunge vor. Sie ist Gegenspieler der Proteasen. Unter ihnen spielt die neutrophile Elastase eine wichtige Rolle, die bei hoher Aktivität zur „Selbstandauung“ der Lunge führt. Bei einem $\alpha 1$-Antitrypsinmangel herrscht ein Ungleichgewicht in der Lunge, welches 
dazu führt, dass Struktur- und Funktionsproteine langsam verloren gehen. Erste klinische Symptome sind Husten und Auswurf. Der Verlauf der Krankheit führt bis zu einer respiratorischen Insuffizienz mit einem Lungenemphysem [4].

e) Sonstige Grunderkrankungen: Verschiedene andere LungenGrunderkrankungen tragen mit 18,1 \% zur Indikation LuTx bei [20]. Hierzu zählen u.a. Erkrankungen wie Sarkoidose und Bronchiektasen.

\subsubsection{Komplikationen nach Lungentransplantation}

Die Langzeitergebnisse zum Überleben nach LuTx haben sich zwar mit 5-10 Jahresüberlebensraten von $54 \%$ bzw. $31 \%$ verbessert, sind aber immer noch unbefriedigend. Im Vergleich dazu liegt z.B. das 5 Jahresüberleben nach Herztransplantation bei $72 \%$ [47,54]. Für diese verhältnismäßig geringen Überlebenswahrscheinlichkeiten sind zahlreiche möglichen Komplikationen und Misserfolge verantwortlich, die aber nicht zwangsläufig zum Tod führen müssen:

a) Abstoßungen: Eine akute Abstoßung tritt zu 33,9\% meist innerhalb der ersten zwei Jahre nach LuTx auf [17]. Bei der chronischen Organdysfunktion (Chronic lung allograft dysfunction, (LAD) und seiner häufigsten Untergruppe dem Bronchiolitis Obliterans Syndrom (BOS) kommt es durch chronische Entzündung zum Epithelverlust, zu Vernarbungen der Bronchien und zu einer Obstruktion der kleinen Atemwege. BOS lässt sich bei $50 \%$ der Patienten 5 Jahre und $75 \%$ der Patienten 10 Jahre nach LUTx nachweisen. BOS wird anhand der forcierten exspiratorischen Einsekundenkapazität (FEV1) bestimmt, welche als das Volumen definiert ist, das nach maximaler Einatmung in einer Sekunde maximal ausgeatmet werden kann und spiegelt die chronische Abstoßung der Lunge wieder. Anhand der FEV1 lässt sich BOS in 3 Schweregrade unterteilen: BOS $1=$ FEV1-Abfall von 20-34 \%, BOS 2 von 35-49\% und bei BOS 3 von $50 \%$ oder mehr, jeweils ausgehend vom Bestwert nach LuTx [10].

b) Infektionen: Infektionen stellen nach LuTx eine maßgebliche Bedrohung dar. Die dauerhafte und hochdosierte Immunsuppression erhöht die Anfälligkeit für Infektionen [26]. Die bakterielle Pneumonie ist daher häufig und bereits vermehrt kurze Zeit nach Tx anzutreffen [1]. Ausgelöst wird diese z.B. durch Streptococcus pneumoniae, Pseudomonas aeruginosa oder Staphylococcus 
aureus. Zudem ist eine erhöhte bakterielle Belastungen der Mundhöhle, unter anderem bei Vorliegen einer Parodontitis, mit einer höheren Anzahl an Pneumonien bei Hochrisiko-Patienten (u.a. Patienten nach LuTx) assoziiert [37]. Im Weiteren kann es zu opportunistischen Infektionen mit dem Cytomegalovirus (CMV), Aspergillus und Pneumocystis jirovecci Pneumonie (PCP) kommen [25].

c) Chirurgische und intensivmedizinische Komplikationen: Die 90-Tage-Mortalität liegt heutzutage bei durchschnittlich $10 \%$ [17]. Darunter fällt vor allem die primäre Transplantdysfunktion (primary graft dysfunktion, PGD), die innerhalb von 72 Stunden nach LuTx eintritt und eine multifaktorielle Schädigung der transplantierten Lunge darstellt. Außerdem sind primär-infektiöse Pneumonien und akute antikörpervermittelte oder zelluläre Abstoßungen zu nennen. Zu den chirurgischen Komplikationen zählen Nachblutungen, ein Missverhältnis zwischen Spender- und Empfänger-Lungengröße sowie Probleme der Gefäß- und Bronchusanastomosen [18].

\subsubsection{Immunsuppression}

LuTx Patienten unterliegen einer dauerhaften Immunsuppression, die für die Organakzeptanz eine unbedingte Notwendigkeit darstellt [33]. Dies bedeutet aber auch, dass die immunsuppremierten Patienten eine verminderte Immunantwort besitzen, wodurch der Organismus in seiner Abwehrfähigkeit von pathogenen Erregern eingeschränkt ist. Daraus resultiert eine erhöhte Infektanfälligkeit [26,27]. Die Standardimmunsuppression nach LuTx besteht in der Regel aus einer Kombination von drei verschiedenen Medikamenten (Immunsuppressiva): ein Glukokortikoid (z.B. Prednisolon), einem Calcineurininhibitor (z.B. Cyclosporin A oder Tacrolimus) sowie einem Zellzyklusinhibitor (z.B. Azatioprin oder Mykophenolat-Mofetil, MMF); alternativ wird auch Cyclosporin A mit einem Profilerationsinhibitor (z.B. Sirolimus oder Everolimus) kombiniert [47].

Die lebenslange Immunsuppression ist von einer Vielzahl an Nebenwirkungen begleitet. Diese unerwünschten Arzneimittelwirkungen spielen eine große Rolle in Bezug auf die langfristige Prognose, Morbidität und Mortalität sowie die Lebensqualität $[33,46]$. Die bekannten Nebenwirkungen der Immunsuppression sind eine erhöhte Infektanfälligkeit $[26,27]$, die Begünstigung eines Diabetes mellitus [40], erhöhte Blutfettwerte, 
Nierenschädigungen, Osteoporose, Muskelschwäche, Erhöhung des Blutdrucks und Erhöhung des langfristigen Risikos für Tumore [6,38,46]. Daneben sind auch orale Nebenwirkungen beschrieben. Zu den häufigsten oralen Nebenwirkungen der dauerhaften Immunsuppression zählen Pilzinfektionen [9] und Gingivahyperplasien, z.B. bedingt durch Cyclosporin A [24]. Da Cyclosporin A seinerseits Nebenwirkungen wie Nephrotoxizität und Hypertension aufweist, wird es häufig zusammen mit Nifedipin verabreicht [24].

\subsection{Mundgesundheit und Transplantation}

\subsubsection{Zahnärztliche Sanierung vor und nach Transplantation}

Organtransplantierte haben, bedingt durch die lebenslange Immunsuppression, ein gesteigertes Risiko für lokale dentale oder daraus entstandene hämatogen fortgeleitete bakterielle Infektionen [36]. Nach einer Stellungnahme der DGZMK (1998) werden Behandlungsempfehlungenfür prä- und post-Tx-Patienten ausgewiesen. Hierbei wird u.a. auf die antibiotische Prophylaxe bei zahnärztlichen Behandlungen nach Tx verwiesen, welche analog zur Endokarditisprophylaxe der American Heart Association erfolgen sollte [36,53]. Einheitliche, internationale Behandlungsrichtlinien fehlen jedoch bisher. Dies erklärt möglicherweise die häufig unzureichende zahnärztliche Versorgung von Tx-Patienten.

Vor Tx ist die Schaffung und Sicherstellung von mundgesunden Verhältnissen anzustreben. Mundgesundheitsprobleme (dental und parodontal) stellen einen potentiell negativen Einfluss auf die Lebensqualität dar und eine suffiziente Mundhygiene sowie deren Erhalt als Beitrag zur Infektionsprophylaxe ist bereits vor Transplantation zu erzielen $[16,30,45]$. Hierbei wird empfohlen, dass die Kandidaten mindestens einmal jährlich eine zahnärztliche Untersuchung durchführen lassen sollten $[15,22,29]$. Eine Studie von Nusime et al. zeigte in diesem Zusammenhang, dass $89 \%$ der befragten deutschen Transplantationszentren eine systematische zahnärztliche Untersuchung vor Transplantation veranlassen [34]. Bei entsprechendem Behandlungsbedarf sollte eine zielgerichtete Sanierung vorgenommen werden, um nach Tx mögliche systemische Komplikationen zu verhindern [16,44]. In einem Beitrag von Schmalz und Ziebolz [44] wird ein ausführlicher Vorschlag für ein Behandlungskonzept 
vor und nach Tx aufgezeigt. Dazu zählen für Tx-Kandidaten neben der gründlichen Anamnese und der Beratung des Patienten über den Zustand als Risikopatient, eine ausführliche klinische und röntgenologische Diagnostik sowie die anschließende individuelle Therapie. Zudem wird auf die Wichtigkeit der frühzeitigen interdisziplinären Zusammenarbeit zwischen Allgemeinmedizinern, Transplantationszentrum und Hauszahnarzt verwiesen [44]. Zu beachten ist, dass die Patienten durch ihre zur Tx führende, im Endstadium befindliche Grunderkrankung und die Einnahme von zahlreichen Medikamenten in ihrem Allgemeinzustand stark eingeschränkt sind [41]. In diesem Zusammenhang erschweren speziell für LuTx-Kandidaten Luftnot und die häufige Notwendigkeit von externer Sauerstoffgabe die Gesamtsituation. Durch die eingeschränkte Belastbarkeit dieser Patienten ist davon auszugehen, dass auch die Durchführung der häuslichen Mundhygiene erschwert ist bzw. nur eingeschränkt ausgeübt wird [44]. Zudem zeigten Studien von Schmickler et. al. und Ziebolz et. al., dass die geforderte Zahnarztkonsultation vor Transplantation mit $83 \%$ und $89 \%$ nicht konsequent wahrgenommen wurde $[45,55]$. Im Weiteren ist völlig unklar, ob nach dem Zahnarztkontakt vor Tx auch daraus folgende und notwendige zahnärztlichen Interventionen konsequent umgesetzt werden bzw. wurden. In diesem Bereich gibt es in der Gesamtversorgung aller Tx-Kandidaten keine eindeutigen Vorgaben, Kontrollmechanismen und fachübergreifende Betreuungskonzepte.

Nach Tx steht die Sicherung der Mundgesundheit mit einer präventionsorientierten Therapie im Vordergrund. Dazu wird den Tx-Patienten empfohlen ein Kontrollintervall von 3 bzw. 6 Monaten in der zahnärztlichen Praxis wahrzunehmen [32,44]. Vorliegende Studien zeigen aber, dass diese engen empfohlenen Kontrollintervalle nicht durchgängig umgesetzt werden [16,23,42,45,50,55]; größere Abstände scheinen dabei ein Indiz für vermehrtes Auftreten von Mundgesundheitsproblemen zu sein [15]. Eine verbindliche und spezifische Leitlinie für die Praxis fehlt bisher noch. Die zahnmedizinische Nachsorge nach Tx umfasst neben dem Abgleich der Anamnese mit ggf. Rücksprache zum Transplantationszentrum, die professionelle Zahnreinigung (PZR) mit Remotivation und Aktualisierung des Befundes sowie die Therapie von neu aufgetretenen oralen Erkrankungen [44]. Aufgrund der dauerhaften Immunsuppression und der Einordnung organtransplantierter Patienten als infektionsgefährdete Hochrisikopatienten $[30,56]$ soll eine prätherapeutische, antibiotische Abdeckung vor zahnärztlichen Eingriffen mit 
erhöhtem Bakteriämierisiko (z.B. Zahnextraktion, Parodontalbehandlung, PZR und Implantation) durchgeführt werden [36,44]. Diese erfolgt in Anlehnung an die Endokarditisprophylaxe-Richtlinie der Deutschen Gesellschaft für Kardiologie (DGK) und der American Heart Association [31,53] und wird weitgehend akzeptiert und angewendet $[16,53,56]$ : Amoxicillin $2 \mathrm{~g}$ oral $1 \mathrm{~h}$ vor Eingriff, bei besonderen Fällen $6 \mathrm{~h}$ danach $1 \mathrm{~g}$ oder bei Penicillin-Unverträglichkeit Clindamycin $600 \mathrm{mg} 1 \mathrm{~h}$ vorher, bei besonderen Fällen 6 h danach 300 mg. Eine spezifische Richtlinie zur Antibiotikaabdeckung für Transplantationspatienten bei zahnmedizinischen Eingriffen gibt es bisher aber nicht [34]. In den ersten 3 Monaten nach Tx sollten zahnmedizinische Eingriffe nur bei vitaler Bedrohung unter enger Kooperation mit dem Tx-Zentrum und elektive Eingriffe erst 6 Monate nach Tx unter oben genannter antibiotischer Abdeckung erfolgen $[36,44]$. Die Studie von Schmickler et. al. zeigt, dass es bei den Tx-Patienten einen Mangel an Information und Aufklärung zur Notwendigkeit eine Antibiotikaprophylaxe bei zahnärztlichen Eingriffen nach Tx gibt. Lediglich $30 \%$ der befragten Patienten nach Leber- und Nierentransplantation gaben an über diesen Zusammenhang informiert worden zu sein [45]. Diese Studie verdeutlicht die Wichtigkeit der frühzeitigen Patientenaufklärung von Seiten des Zahnarztes bzw. TxZentrums und die Forderung nach einheitlichen und verbindlichen Richtlinien zur zahnmedizinischen Betreuung organtransplantierter Patienten.

\subsubsection{Mundgesundheitsverhalten nach Transplantation}

Über das Mundgesundheitsverhalten nach Tx liegen nicht viele und speziell nach LuTx keine Informationen vor. Verfügbare Studien lassen Defizite beim Mundhygieneverhalten von Patienten nach Leber-, Nieren- und Herz-Tx feststellen $[23,42,45,55]$. Dies zeigt sich durch eine geringe bzw. keine gesteigerte Nutzung von zusätzlichen Mundhygienehilfsmitteln wie Zahnseide und Interdentalbürstchen mit maximal $27-50 \%$. Lediglich 10-25 \% der untersuchten Patienten gaben an, sich mehr als 2 mal pro Tag die Zähne zu putzen $[23,42,45,55]$. Eine mögliche Ursache liegt in der mangelnden Aufklärung zur Mundgesundheit und Information bzw. Sensibilisierung über den Zusammenhang von Mundgesundheit und Tx. So gaben nur 51 \% bzw. 30 \% der untersuchten Patienten nach Tx an ausreichend informiert worden zu sein $[45,55]$. 
Auch anhand des zahnärztlichen Kontrollverhaltens lassen sich Defizite festmachen. In den vorliegenden Studien verschiedener Tx-Patientengruppen (ohne LuTx) gaben 45-83 \% der befragten Patienten an regelmäßig einen Zahnarzt aufzusuchen; damit liegt die Rate an unregelmäßigen Kontrollen bei mindestens $20 \%$. Dabei ist die letzte zahnärztliche Untersuchung bei 7-15 \% der untersuchten Patienten nach Tx (Leber, Niere, Herz) über 12 Monate zurückliegend [23,42,45,55] und kommt damit den oben genannten Forderungen nach Kontrolluntersuchungen im Abstand von 3 bzw. 6 Monaten nicht annähernd nach $[32,44]$. Zudem wurde ein rein beschwerdebedingter Zahnarztkontakt bei $7-18 \%$ der untersuchten Tx-Patienten festgestellt $[42,45,55]$.

Zusammenfassend sollte zwingend bei Organtransplantierten durch ausführliche Mundhygieneinstruktion und Motivation sowie durch Information zur Notwendigkeit der regelmäßigen zahnärztlichen Betreuung dem reduzierten Mundgesundheitsverhalten entgegengewirkt werden.

\subsubsection{Mundgesundheitszustand nach Transplantation}

Patienten nach Tx haben mundgesundheitsspezifische Besonderheiten und zeigen durch ihre lebenslange Immunsuppression eine erhöhte Infektanfälligkeit einerseits in der Mundhöhle aber auch im Gesamtorganismus [27]. Eine verstärkte Prävalenz von oralen Erkrankungen ist deshalb denkbar. Für Patienten nach LuTx liegen bisher keine Daten zur Mundgesundheitssituation vor. Grundsätzlich ist die frühzeitige Schaffung mundgesunder Verhältnisse und deren langfristiger Erhalt als Teil der Infektionsprophylaxe bereits vor Tx anzustreben [16,30,45]. Verfügbare Studien anderer Organtransplantierter (Leber, Niere, Herz) lassen aber eine hohe Prävalenz oraler Erkrankungen feststellen $[23,39,42,45,55]$.

Ein nach $T x$ zu vermutender verbesserter Zahnstatus und eine niedrigere Kariesprävalenz, durch die geforderte vorausgegangene Sanierung sowie konsequenter engmaschiger Nachsorge, konnte bisher in keiner Untersuchung festgestellt werden $[23,42]$. Während Patienten nach Tx eine vergleichbare Karieserfahrung zur deutschen Allgemeinbevölkerung (65-74 Jahre) aufweisen, ist eine deutlich höhere Kariesprävalenz (D-T) festzustellen. Entsprechend ist der Sanierungsgrad verbesserungsfähig $[21,42,45,55]$. 
Die Prävalenz von moderater und schwerer Parodontitis (65-90 \%) nach Tx ist ebenfalls deutlich erhöht $[23,39,42,45,55]$. Dies spricht möglicherweise für ein mangelndes standardisiertes Screening sowie eine fehlende parodontale Sanierung vor Tx. In der älteren Gruppe der deutschen Allgemeinbevölkerung (65-74 Jahre) liegt die Prävalenz für moderate und schwere Parodontitis dagegen bei 65 \% [21]. Der hohe parodontale Behandlungsbedarf (55-79 \%) bei Patienten nach Tx weist ebenfalls auf die schlechte parodontale Gesundheit sowie ausbleibende Parodontalbehandlung dieser Patientengruppe hin $[23,42,45]$ und sollte eigentlich nach gründlicher und erfolgreicher parodontaler Sanierung prätransplant nach Tx deutlich geringer sein $[23,42,45,55]$. Gerade die starke parodontale Entzündung könnte durch die hohe Immunsuppression beeinflusst werden und zu möglichen Komplikationen post Tx, wie z.B. akute Abstoßungsreaktion und BOS nach LuTx führen [19,39,57]. Zudem können sich die Bakterien über das Blut verteilen und das Bakteriämierisiko steigt bei schlechter Mundhygiene an [14]. Bei Patienten mit schlechter Mundhygiene und Parodontitis ist eine Bakteriämie im Vergleich zu Patienten mit gesundem Parodont schwerer und langanhaltender $[49,53]$. Ebenso sind einige Erreger der Mundhöhle an der Entwicklung systemischer Erkrankungen wie Pneumonien oder kardiovaskulärer Erkrankungen beteiligt $[8,35]$.

Insgesamt handelt es sich scheinbar bei Organtransplantierten um eine Gruppe von Risikopatienten, deren Mundgesundheitszustand nicht den geforderten Bedingungen nach frühzeitiger zahnärztlicher Sanierung vor Tx und langfristiger Nachsorge nach Tx nachkommt $[23,30,42,45]$.

In einer retrospektiven Studie von Melkos et al. wurde festgestellt, dass die Rate an Komplikationen nach Tx, wie Infektionen und Abstoßungen, bei nicht abgeschlossener zahnmedizinischer Behandlung bzw. Sanierung vor Tx mit 80 \% zu 45,5 \% deutlich höher ist [30]. Dem gegenüber steht die Studie von Walterspacher et al. mit Patienten vor und nach LuTx. Hier konnte in der Nachsorge kein Infektionsfokus an den Zähnen ausgemacht werden. Allerdings beruft sich Walterspacher lediglich auf den Bericht durch den Patienten; es wurde keine zahnmedizinische Kontrolluntersuchung nach LuTx durchgeführt [52]. Bisher fehlen umfangreiche Studien, welche die Infektionsraten in großen Patientengruppen nach Tx mit standardisierten Verfahren erheben. 
Ein weiteres Problem bei Organtransplantierten und auch speziell nach LuTx sind die oralen Nebenwirkungen der Immunsuppression, wie Veränderungen der Mundschleimhaut, Gingivawucherungen und Pilzerkrankungen beispielsweise mit Candida Albicans $[9,24,44]$. Gerade bei den Gingivawucherungen, als multifaktorielles Geschehen durch Reaktion von Medikamenten, Metaboliten und Fibroblasen, wird dem Mundgesundheitszustand eine entscheidende Rolle zugeschrieben [2]. Neben den oralen Nebenwirkungen sind auch systemische Auswirkungen der dauerhaften Immunsuppression zu nennen. Dazu gehören u.a. Hyperlipidämie, arterieller Hypertonus und insulinpflichtiger Posttransplantdiabetes $[40,46]$.

Gerade nach LuTx muss die nahe anatomische Beziehung der Mundhöhle mit direkter Verbindung zum Transplantat beachtet werden. In einer Pilotstudie untersuchten Irani et al. diesen Zusammenhang und konnte in einer sehr kleinen Patientengruppe feststellen, dass bei verstärktem Vorkommen von potenziell parodontalpathogenen Bakterien in der oralen Plaque, diese auch in der Lunge nachzuweisen sind und die Patienten ebenfalls unter BOS leiden [19]. Das wiederum verstärkt den Ruf nach einer konsequenten und frühzeitigen Sanierung vor LuTx mit dem Ziel Erkrankungen der Mundhöhle zu erkennen, zu therapieren und langfristig präventiv vorzubeugen bzw. gesunde Verhältnisse zu erhalten, um die Nebenwirkungen, Komplikationen und Erkrankungen nach LuTx so gut wie möglich zu reduzieren. 


\subsection{Zielsetzung und Fragestellung der vorliegenden Studie}

Ziel dieser Studie war es, einen möglichst umfassenden Überblick über den Mundgesundheitszustand (dental und parodontal), das Mundgesundheitsverhalten sowie das Bewusstsein für die Notwendigkeit einer guten Mundhygiene von Patienten nach LuTx zu gewinnen.

Die folgende Arbeitshypothese wurde aufgestellt:

- Die Prävalenz parodontaler Erkrankungen von Patienten nach LuTx unterscheidet sich von der Deutschen Allgemeinbevölkerung (Vierte Deutsche Mundgesundheitsstudie / DMS IV). 


\section{Publikationsmanuskript}

Marcinkowski A, Ziebolz D, Kleibrink B.E, Weinreich G, Kamler M, Teschler $H$, Sommerwerck U

Deficits in oral health behavior and oral health status in patients after lung transplantation

Clinical Respiratory Journal. 2016 Nov 18. doi: 10.1111/crj.12585. [Epub ahead of print] (Impact factor: 2.356) 


\title{
Deficits in oral health behavior and oral health status in patients after lung transplantation
}

\author{
Anna Marcinkowski $^{1}$ ｜ Dirk Ziebolz ${ }^{1}$ | Bjoern E. Kleibrink ${ }^{2}$ ｜ Gerhard Weinreich $^{2}$ | \\ Markus Kamler $^{3}$ | Helmut Teschler ${ }^{2}$ | Urte Sommerwerck ${ }^{2}$
}

${ }^{1}$ Department of Cariology,

Endodontology and Periodontology,

University of Leipzig, Leipzig,

Germany

${ }^{2}$ Department of Pneumology,

Ruhrlandklinik, West German Lung

Center, University Hospital Essen,

University Duisburg-Essen, Essen,

Germany

${ }^{3}$ Department of Thoracic

Transplantation, University Hospital

Essen, University Duisburg-Essen,

Essen, Germany

\section{Correspondence}

Dr. Urte Sommerwerck, Department of Pneumology, Ruhrlandklinik,

West German Lung Center,

University Hospital Essen,

University Duisbug-Essen,

Tüschener Weg 40, 45239 Essen,

Germany.

Email: urte.sommerwerck@ruhrland-

klinik.uk-essen.de

\section{Funding information}

This study is registered at the

German Clinical Trials Register

(DRKS00005746).

\begin{abstract}
Background: Dental status has been implicated in several systemic inflammatory diseases and is a potential focus for systemic infections. Therefore, most lungtransplant centers have recommendations regarding pre-transplant dental care and follow-up, but there are no official clinical guidelines. To date there is little information on oral health status in lung transplant (LTx) recipients. The aim of this study was to systematically assess oral health status in LTx recipients.
\end{abstract}

Objectives: The aim of this study was to assess oral health status, including periodontal disease, oral health behavior, and awareness of the need for good oral health after LTx.

Methods: LTx recipients were recruited during follow-up outpatient visits at a university clinic transplant unit. Oral health status was quantified using the count of Decayed, Missing, and Filled Teeth (DMF-T) and the grade of periodontal disease was measured by probing depth. Patients' oral health behavior was assessed using a questionnaire.

Results: Seventy-three patients were included at $5.8 \pm 3.4$ years after lung transplantation. The mean DMF-T was 21.9 \pm 5.5 . Patients with cystic fibrosis as the indication for transplantation had a significantly lower DMF-T than patients with chronic obstructive pulmonary disease as the transplant indication. Of the 66 patients with teeth, $97 \%$ had moderate or severe periodontal disease. The prevalence of moderate or severe periodontal disease was significantly higher in LTx recipients (mean age 55.9 years) compared with older individuals (age 65-74 years) from the German general population $(P<.005)$.

Conclusions: This single center study shows deficits in oral health and oral health behavior in patients after LTx. There is a strong need for interdisciplinary collaboration and clinical guidelines to foster better oral health education of the transplant recipient and better oral health.

\section{K E Y W O R D S}

dental care, lung transplantation, oral health, oral hygiene, periodontitis

Abbreviations: A1AT, alpha-1 antitrypsin deficiency; BOP, bleeding on probing; CAL, clinical attachment loss; CF, cystic fibrosis; COPD, chronic obstructive pulmonary disease; D, decayed; D-T, decayed teeth; DMF-T, Decayed, Missing and Filled Teeth Index; DMS IV, Fourth German Oral Health Study; F, filled; F-T, filled teeth; ILD, interstitial lung diseases; IQR, interquartile range; LTx, lung transplant; M, missing; M-T, missing teeth; MMF, Mycophelolat Mofetil; PPD, periodontal probing depth; SD, standard deviation; Tx, transplantation.

Anna Marcinkowski and Dirk Ziebolz have contributed equally to this work. 


\section{1 | INTRODUCTION}

Regardless of the underlying disease, to be eligible for lung transplantation patients must have a 2-year survival probability of less than $50 \%$ with a markedly reduced quality of life due to respiratory failure after all other treatment options have been exhausted. ${ }^{1}$ Diseases that may progress to the point where lung transplantation is an option include chronic obstructive pulmonary disease (COPD), interstitial lung diseases (ILD), cystic fibrosis (CF), alpha-1 antitrypsin (A1AT) deficiency, and other rare conditions. ${ }^{2}$

Lung transplant (LTx) is an important therapeutic option for end-stage lung disease but long-term outcomes are unsatisfactory compared with other solid organ transplantations, with 5- and 10-year survival rates of 54\% and 31\%, respectively. One of the reasons for the worse outcome is the occurrence of infectious complications, which cause $37.4 \%$ of reported deaths in the first year post-LTx and about 22.3\% of deaths after the third year. ${ }^{3}$ Indefinite triple immunosuppression is the standard treatment for LTx recipients. The high doses of immunosuppression required by these patients compared with other solid organ transplant recipients increases the susceptibility to infections. ${ }^{4}$

The oral cavity, containing more than 700 different strains of bacteria, ${ }^{5}$ has been implicated in the development of several systemic diseases, including cardiovascular disease and pneumonia. ${ }^{6,7}$ In particular, the primary cause of periodontitis is microbial colonization of the oral cavity with complex, structured subgingival biofilms composed of different periodontal pathogenic bacteria, mainly gram-negative species. ${ }^{8}$

Bacteria can spread via swallowing, aspiration or through bacteremia, which can occur as a result of injuries to the oral mucosa that might happen during tooth brushing and chewing. ${ }^{9}$ The risk of bacteremia increases in the presence of bad oral hygiene and periodontitis, ${ }^{10}$ and bacteremia is more severe and prolonged in patients with bad oral hygiene and periodontal disease compared with those with healthy periodontal status. ${ }^{9,11}$ Increased bacterial load in the oral cavity and periodontitis have been associated with a higher rate of pneumonias, ${ }^{12}$ which is a common complication after lung transplantation. ${ }^{13}$

Early dental screening and treatment before transplantation are a recommended infection prophylaxis measure and are widely implemented. ${ }^{14}$ In patients undergoing renal, liver or heart transplantation, yearly pre-transplant dental examinations are recommended, ${ }^{15-17}$ but medical practice guidelines are missing. Regular dental examinations are part of many transplant programs, but there are no specific recommendations for dental treatment before lung transplantation.

Reducing plaque burden is one strategy to decrease bacteremia risk before dental treatment of post-transplant patients, and administration of prophylactic antibiotics is another. How- ever, although there is a pathophysiological basis for recommending antibiotic prophylaxis, there are no evidence-based guidelines. The most widely accepted recommendation is to adhere to guidelines for the prevention of endocarditis. ${ }^{11,14}$

Studies in recipients of other solid organ transplants (liver, heart, renal) showed deficits in oral health and oral health behavior. Reasons for this were insufficient education, lack of accepted guidelines, low awareness of oral hygiene issues and a lack of knowledge about the possible consequences for overall health. ${ }^{15,18}$ There is only one published study on oral health in LTx patients prior to transplantation ${ }^{19}$ and none after the transplantation procedure.

The aim of this study was to assess oral health status, including periodontal disease, oral health behavior, and awareness of the need for good oral health after LTx. We hypothesized that the prevalence of periodontal disease in LTx recipients would differ from that in the German general population of the Fourth German Oral Health Study (DMS IV). ${ }^{20}$

\section{2 | MATERIAL AND METHODS}

This single-center, cross-sectional study was approved by the ethics committee of the University Hospital Essen (13-5689BO) and was registered at the German Clinical Trials Register (DRKS00005746).

\section{1 | Patients}

Patients aged $\geq 18$ years were recruited during their routine outpatient visits to the lung transplant unit of the Ruhrlandklinik, Essen, Germany between February and October 2014. Patients had to have undergone lung transplantation at least six months previously and be free from infections at the time of their clinic visit. Patients with hepatitis, HIV, or mental illnesses were excluded, as were those unable to understand the informed consent documents, and pregnant women. Patients were informed verbally and in writing about the study and gave written informed consent to participate.

\subsection{Patient questionnaire}

Study participants were asked to complete a questionnaire regarding their medical and dental history, prior education about oral health and oral health behavior. Questions asked related to: immunosuppression and medication, smoking status (smokers were defined as patients who smoked at the time of examination, former smoker were defined as patients who have ever smoked till time of examination), whether information about the associations between oral health and lung transplantation had been provided, and whether a dental check-up or comprehensive dental treatment had taken place before transplantation. Patients were supervised while they completed the questionnaire. 
TABLE 1 Demographic and clinical characteristics of the study population

\begin{tabular}{|c|c|c|c|c|c|c|}
\hline & & Indication fo & ng transplan & & & \\
\hline & $\begin{array}{l}\text { Total } \\
(n=73)\end{array}$ & $\begin{array}{l}\text { COPD } \\
(n=29)\end{array}$ & $\begin{array}{l}\text { ILD } \\
(n=22)\end{array}$ & $\begin{array}{l}\text { CF } \\
(n=5)\end{array}$ & $\begin{array}{l}\text { A1-AT- } \\
\text { deficiency } \\
(n=10)\end{array}$ & $\begin{array}{l}\text { Other } \\
(n=7)\end{array}$ \\
\hline Age, years & $55.9 \pm 9.4$ & $59.5 \pm 5.4$ & $58.1 \pm 6.8$ & $34.4 \pm 8.7$ & $54.5 \pm 9.8$ & $51.1 \pm 8.6$ \\
\hline Male, $n(\%)$ & $36(49.3)$ & $11(37.9)$ & $17(77.3)$ & $2(40.0)$ & $5(50.0)$ & $1(14.3)$ \\
\hline Smoking status & & & & & & \\
\hline Nonsmoker, $n(\%)$ & $25(34.2)$ & $2(6.9)$ & $11(50.0)$ & $5(100.0)$ & $1(10.0)$ & $6(85.7)$ \\
\hline Former smoker, $n(\%)$ & $48(65.8)$ & $27(93.1)$ & $11(50.0)$ & $0(0)$ & $9(90.0)$ & $1(14.3)$ \\
\hline Smoker, $n(\%)$ & $0(0)$ & $0(0)$ & $0(0)$ & $0(0)$ & $0(0)$ & $0(0)$ \\
\hline Pack-years & $19.8 \pm 24.4$ & $33.4 \pm 22.5^{*}$ & $11.4 \pm 27.6$ & $0 \pm 0$ & $21.0 \pm 11.8$ & $2.3 \pm 6.1$ \\
\hline Time since $T x$, years & $5.8 \pm 3.4$ & $6.1 \pm 2.9$ & $4.8 \pm 3.6$ & $6.9 \pm 3.5$ & $6.7 \pm 4.2$ & $5.7 \pm 3.6$ \\
\hline Immunosuppression, $n(\%$ & & & & & & \\
\hline $\begin{array}{l}\text { Tacrolimus + MMF } \\
+ \text { glucocorticosteroids }\end{array}$ & $43(58.9 \%)$ & $18(62.1 \%)$ & $11(50.0 \%)$ & $4(80.0 \%)$ & $5(50.0 \%)$ & $5(71.4 \%)$ \\
\hline $\begin{array}{l}\text { Cyclosporin + MMF } \\
+ \text { glucocorticosteroids }\end{array}$ & $13(17.8 \%)$ & $5(17.2 \%)$ & $5(22.7 \%)$ & $1(20.0 \%)$ & $2(20.0 \%)$ & $0(00 \%)$ \\
\hline $\begin{array}{l}\text { Sirolimus + MMF } \\
+ \text { glucocorticosteroids }\end{array}$ & $12(16.4 \%)$ & $4(13.8 \%)$ & $6(27.3 \%)$ & $0(0.0 \%)$ & $1(10.0 \%)$ & $1(14.3 \%)$ \\
\hline Other & $5(6.8 \%)$ & $2(6.9 \%)$ & $0(0.0 \%)$ & $0(0.0 \%)$ & $2(20.0 \%)$ & $1(14.3 \%)$ \\
\hline
\end{tabular}

Values are mean \pm standard deviation, or number of patients (\%).

$* P<.006$ vs. ILD, $P<.022$ vs. $\mathrm{CF}$ and $P<.011$ vs. other diseases.

A1-AT, alpha-1 antitrypsin; CF, cystic fibrosis; COPD, chronic obstructive pulmonary disease; ILD, interstitial lung disease;

MMF, mycophenolate mofetil; Tx, transplant.

\section{3 | Dental examination}

Patients underwent a standardized dental examination one hour after a single injected dose of prophylactic antibiotics as described by Nusime et al. (amoxicillin $2 \mathrm{~g}$ or clindamycin $600 \mathrm{mg}$ at the discretion of the treating physician). ${ }^{21}$ The examination included inspection of the mucosa, dental status, and assessment of periodontal disease.

\subsubsection{Inspection of the oral mucosa}

The first part of the dental examination consisted of visual inspection of the oral mucous membranes. In addition to clinical signs of a viral or fungal infection (e.g., mucositis or thrush), existing gingival overgrowth was recorded.

\subsection{2 $\mid$ Dental status (DMF-T)}

The DMF-T was assessed visually using a mirror and probe, and determined based on the number of decayed, missing and filled teeth. All teeth with reasonable suspicion for defects of the dentine layer were categorized as D (decayed), all filled and crowned teeth were classified as F (filled) and missing teeth were assigned to the M (missing) category. Therefore, the DMF-T reflects the current and past caries burden of the patient. The degree of caries restoration was calculated as the ratio of filled teeth to the sum of carious and filled teeth. ${ }^{22}$

\subsection{3 $\mid$ Periodontal examination}

The periodontal condition was determined using a millimeter-scaled periodontal probe (PCP 15, Hu-Friedy, Chicago), and included periodontal probing depth (PPD), clinical attachment loss (CAL) and the occurrence of bleeding on probing (BOP) at six assessment points per tooth. Measurements were recorded with the Paro-Status software (Berlin, Germany). Periodontitis was graded in three categories according to the definition of Page and $\mathrm{Eke}^{23}$ : (a) severe, (b) moderate, and (c) no/mild periodontitis.

\subsection{Statistical analysis}

Descriptive statistics are expressed as mean \pm standard deviation (SD) for normally distributed data and median with interquartile range (IQR) for non-normal distributed data. Student's $t$-test was used for the comparison of mean values and ANOVA with Bonferroni post-hoc tests was used for the comparison of multiple mean values. A $P$-value of $>.05$ was considered statistically significant. Fisher's exact test was used for categorical variables. 


\section{3 | RESULTS}

\section{1 | Patient characteristics}

Of the 83 patients asked to participate, 73 (36 male, mean age $55.9 \pm 9.4$ years) were included in this study; mean time since transplantation was $5.8 \pm 3.4$ years. Patient characteristics for the total cohort and in subgroups based on underlying lung disease are shown in Table 1. The most common underlying disease was COPD, followed by ILD. Smoking history (pack-years) was significantly higher in patients with COPD compared with most other patient subgroups (Table 1). Most patients were on triple immunosuppression.

\section{2 | Oral health behavior}

The majority of patients $(86.3 \%)$ reported that they visited their dentist on a regular basis (Table 2). All patients were seen by a dentist before transplantation, which resulted in almost three-quarters being treated for dental or oral pathology (Table 2). Very few reported having been treated for periodontal disease during their pre-transplant visits (Table 2). Education about oral health requirements and oral health behavior was provided to nearly three-quarters of patients, and the provider was most often the transplant center (Table 2). Approximately $80 \%$ of patients were aware of the need for antibiotic prophylaxis (Table 2). Almost all patients reported that they brushed their teeth at least once a day, but less than one-third said they used dental floss or interdental brushes (Table 2).

\section{3 | Dental examination}

\subsection{1 | Inspection of the oral mucosa}

Gingival overgrowth at more than one location was seen in one patient $(1.5 \%)$, and three patients had gingival overgrowth at a single location. There were no clinical signs of fungal or viral infections.

\subsection{2 | Dental status (DMF-T)}

Seven patients (10\%) were edentulous. Dental status results are reported in Table 3; the mean DMF-T was 21.9 \pm 5.4 , with some variation between patients with different underlying diseases (Table 3). There were also some significant differences between patient subgroups with respect to the number of missing teeth (Table 3). Figure 1 showed the comparison of DMF-T for the LTx recipients in this study with the German general population (DMS IV); findings in LTx recipients (mean age 55.9 \pm 9.4 years) were similar to those in senior citizens (age 65-74 years). Table 4 presents the dental status of the current study in comparison to the German general population (DMS IV and V) (Table 4).

\subsection{3 | Periodontal disease}

Almost all (97\%) of the 66 dentulous LTx recipients had moderate to severe periodontal disease (Table 3). The prevalence of moderate periodontal disease in LTx recipients was higher than that in the adult and senior citizen age groups of the general population (64\% vs. $53 \%$ and $48 \%$, respectively) (Figure 2). LTx recipients had a significantly higher prevalence of moderate or severe periodontal disease than senior citizens in the German general population (DMS IV; $P<.05$ ) (Figure 2). Table 4 presents the prevalence of periodontitis of the current study in comparison to the German general population (DMS IV and V) (Table 4).

\section{4 | DISCUSSION}

The results of this single-center study showed that the oral health of LTx recipients was insufficient. There was a high rate of current and previous caries exposure, demonstrated by high DMF-T values, and a low degree of caries restoration. In addition, the prevalence of moderate and severe periodontal disease was significantly higher than in the German general population. Oral health behavior was also in need of improvement, because $14 \%$ of LTx recipients reported not seeing a dentist on a regular basis and $21 \%$ said that they were not aware of the recommendations for antibiotic prophylaxis during dental treatments. One-quarter of patients who had undergone lung transplantation reported that they did not feel sufficiently educated about oral health recommendations after LTx.

It is important to note that the findings of this study came from a transplant center that requires a dentist visit before transplantation and recommends antibiotic treatment before dental interventions. A previous study reported that $89 \%$ of German transplant centers reported that they require a dentist visit before transplantation and $83 \%$ recommended predental antibiotic therapy to transplanted patients. ${ }^{21}$ Therefore, oral health status and oral health behavior in transplant recipients at centers not advising these measures might be even worse than reported in this current study.

Compared with a study of oral health behavior after other solid organ transplantation, ${ }^{18}$ more LTx recipients reported feeling educated (74\% vs. $30 \%)$ and there was also a higher rate of follow-up adherence ( $86.3 \%$ vs. $45 \%$ ). With $26 \%$ of solid organ transplant recipients not knowing about the special considerations for LTx recipients, it is not surprising that a substantial percentage (39.7\%) had not seen a dentist in the last 6 months, which is an interval generally considered adequate for high-risk patients. ${ }^{24}$ Compared with a study conducted in Hungarian solid organ transplant recipients that reported a mean time of 22.4 months until the follow-up examination, ${ }^{25}$ the LTx recipients in our study showed better adherence to the recommended follow-up intervals, with $82.2 \%$ having seen a dentist in the last 12 months. However, 
TABLE 2 Oral health questionnaire findings

\begin{tabular}{|c|c|c|c|c|c|c|}
\hline \multirow[b]{2}{*}{$\begin{array}{l}\text { Response, } \\
n(\%)\end{array}$} & \multirow[b]{2}{*}{$\begin{array}{l}\text { Total } \\
(n=73)\end{array}$} & \multicolumn{5}{|c|}{ Indication for lung transplantation } \\
\hline & & $\begin{array}{l}\text { COPD } \\
(n=29)\end{array}$ & $\begin{array}{l}\text { ILD } \\
(n=22)\end{array}$ & $\begin{array}{l}\mathbf{C F} \\
(n=5)\end{array}$ & $\begin{array}{l}\text { A1-AT- } \\
\text { deficiency } \\
(n=10)\end{array}$ & $\begin{array}{l}\text { Other } \\
(n=7)\end{array}$ \\
\hline Regular contact with a dentist & $63(86.3)$ & $22(75.9)$ & $21(95.5)$ & $4(80.0)$ & $10(100.0)$ & $6(85.7)$ \\
\hline \multicolumn{7}{|l|}{ Last dentist visit } \\
\hline $0-3$ months & $29(39.7)$ & $10(34.5)$ & $12(54.5)$ & $2(40.0)$ & $2(20.0)$ & $3(42.9)$ \\
\hline 3-6 months & $15(20.5)$ & $4(13.8)$ & $5(22.7)$ & $1(20.0)$ & $3(30.0)$ & $2(28.6)$ \\
\hline 6-12 months & $16(21.9)$ & $7(24.1)$ & $3(13.6)$ & $2(40.0)$ & $3(30.0)$ & $1(14.3)$ \\
\hline$>12$ months & $13(17.8)$ & $8(27.6)$ & $2(9.1)$ & $0(0.0)$ & $2(20.0)$ & $1(14.3)$ \\
\hline \multicolumn{7}{|l|}{ Reasons for dentist visit } \\
\hline Maintenance & $56(76.7)$ & $23(79.3)$ & $17(77.3)$ & $5(100.0)$ & $7(70.0)$ & $4(57.1)$ \\
\hline Problem & $8(11.0)$ & $0(0.0)$ & $4(18.2)$ & $0(0.0)$ & $1(10.0)$ & $3(42.9)$ \\
\hline Dentist consultation before Tx & $73(100.0)$ & $29(100.0)$ & $22(100.0)$ & $5(100.0)$ & $10(100.0)$ & $7(100.0)$ \\
\hline Dental treatment/therapy before $\mathrm{Tx}$ & $54(74.0)$ & $24(82.8)$ & $14(63.6)$ & $4(80.0)$ & $9(90.0)$ & $3(42.9)$ \\
\hline Periodontitis before $\mathrm{Tx}$ & $2(2.7)$ & $0(0.0)$ & $2(9.1)$ & $0(0.0)$ & $0(0.0)$ & $0(0.0)$ \\
\hline \multicolumn{7}{|l|}{ Information/education on oral health in transplant } \\
\hline Total & $54(74.0)$ & $19(65.5)$ & $16(72.7)$ & $5(100.0)$ & $9(90.0)$ & $5(71.4)$ \\
\hline By dentist & $9(12.3)$ & $3(10.3)$ & $3(13.6)$ & $1(20.0)$ & $1(10.0)$ & $1(14.3)$ \\
\hline By Tx center & $48(65.8)$ & $17(58.6)$ & $14(63.6)$ & $5(100.0)$ & $8(80.0)$ & $4(57.1)$ \\
\hline $\begin{array}{l}\text { Information education on medication-related } \\
\text { gingival overgrowth or on oral } \\
\text { mucosa-related side effects }\end{array}$ & $27(37.0)$ & $14(48.3)$ & $4(18.2)$ & $3(60.0)$ & $3(30.0)$ & $3(42.9)$ \\
\hline $\begin{array}{l}\text { Information/knowledge of the need for } \\
\text { antibiotic prophylaxis }\end{array}$ & $58(79.5)$ & $24(82.8)$ & $18(81.8)$ & $4(80.0)$ & $6(60.0)$ & $6(85.7)$ \\
\hline \multicolumn{7}{|l|}{ Teeth brushing } \\
\hline$<1 \times /$ day & $1(1.4)$ & $1(3.4)$ & $0(0.0)$ & $0(0.0)$ & $0(0.0)$ & $0(0.0)$ \\
\hline $1-2 \times /$ day & $52(72.2)$ & $19(65.6)$ & $16(72.7)$ & $4(80.0)$ & $8(80.0)$ & $5(71.4)$ \\
\hline $3 \times /$ day & $19(26.4)$ & $8(27.6)$ & $6(27.3)$ & $1(20.0)$ & $2(20.0)$ & $2(28.6)$ \\
\hline \multicolumn{7}{|l|}{ Oral hygiene aids } \\
\hline Manual toothbrush & $44(60.3)$ & $14(48.3)$ & $13(59.1)$ & $4(80.0)$ & $9(90.0)$ & $5(57.1)$ \\
\hline Power toothbrush & $29(39.7)$ & $12(41,4)$ & $9(40.9)$ & $2(40.0)$ & $4(40.0)$ & $2(28.6)$ \\
\hline Floss/inter-dental brush & $22(30.1)$ & $7(24.1)$ & $9(40.9)$ & $1(20.0)$ & $3(30.0)$ & $2(28.6)$ \\
\hline Mouth rinse & $20(27.4)$ & $6(20.7)$ & $5(22.7)$ & $2(40.0)$ & $3(30.0)$ & $4(57.1)$ \\
\hline
\end{tabular}

A1-AT, alpha-1 antitrypsin; CF, cystic fibrosis; COPD, chronic obstructive pulmonary disease; ILD, interstitial lung disease; Tx, transplant.

different health care systems and reimbursement plans could contribute to this finding. In the current study, it was also found that the proportion of LTx recipients who see a dentist on regular basis was slightly higher compared with the German general population, about three-quarters of whom see a dentist regularly. ${ }^{20}$

Despite the high prevalence of periodontal disease, only a few periodontal treatments were carried out pre transplant according to the questionnaire data. There are different possible reasons for the low periodontal treatment rate pre transplant. One is the lack of standardized screening and a lot of the diseases might have been overlooked as a result. Another reason might be the lack of understanding of the interrelationship and importance of periodontitis and transplantation. In addition, oral treatment might be perceived as burdensome in patients with end-stage lung disease and shortness of 


\section{DMF-T}

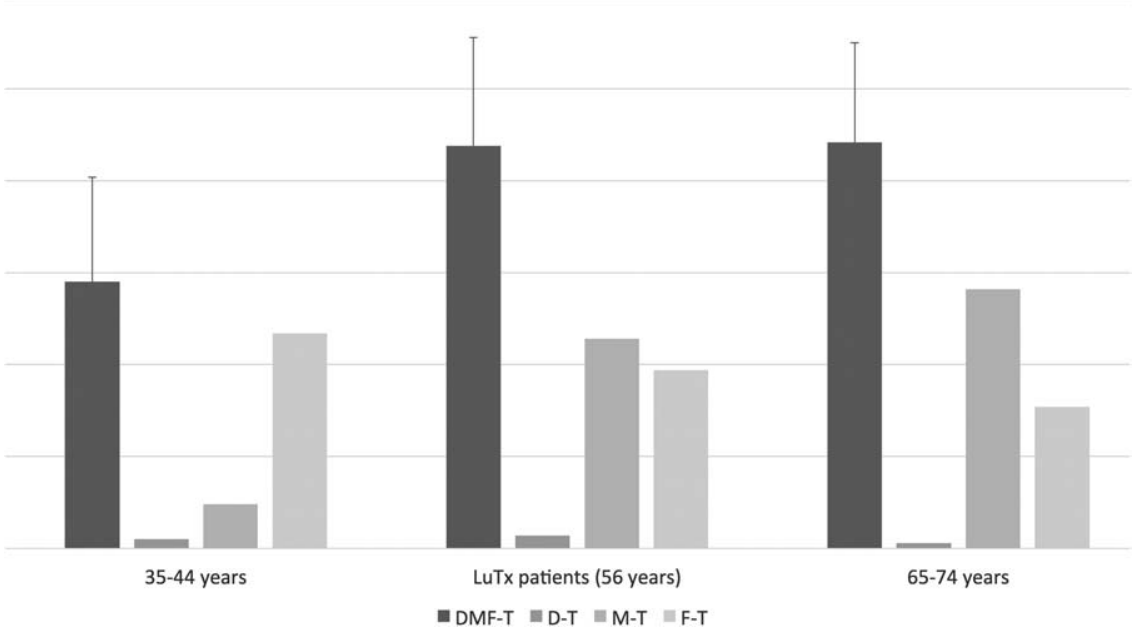

FIGURE 1 DMF-T overall and subcomponent scores in toothed lung transplant recipients $(n=66)$ compared with adults $(n=904)$ and senior citizens $(n=786)$ of the German general population in the Deutsche Mundgesundheitsstudie IV. ${ }^{20}$

breath. And as a consequence dentists might try to keep treatment times short and reduce the treatment to obvious dental foci. There is always the possibility of error in the patient questionnaires but a time consuming treatment would have been remembered by the patient. Therefore, no consul- tation and adjustment with the respective dentists was performed.

Awareness of the need for antibiotic prophylaxis was reported by only $79.5 \%$ of LTx recipients in this study. In addition, general oral health education was reported as

TABLE 3 Dental status based on the decayed, missing, and filled teeth survey

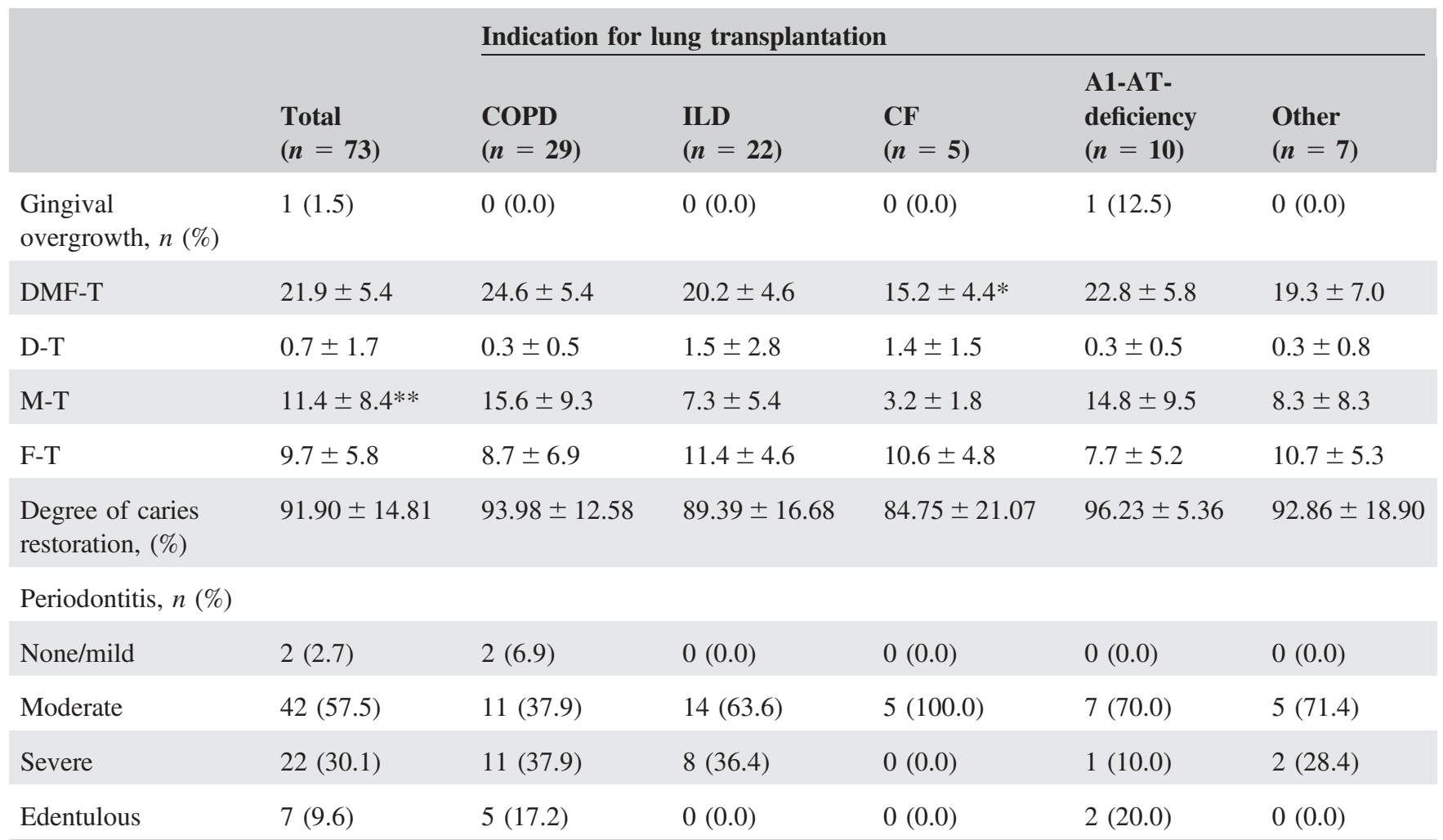

Values are mean \pm standard deviation, or number of patients $(\%)$.

$* P<.02$ vs. COPD, $P=.052$ vs. A1-AT; $P=.004$ vs. ILD, $P=.019$ vs. CF.

A1-AT, alpha-1 antitrypsin; CF, cystic fibrosis; COPD, chronic obstructive pulmonary disease; DMF-T, Decayed, Missing and Filled Teeth; D-T, Decayed Teeth; F-T, Filled Teeth; ILD, interstitial lung disease; M-T, Missing Teeth. 
TABLE 4 Dental findings (DMF-T) and periodontal findings of the Fourth and Fifths German Oral Health Study (DMS IV and V) and the present study

\begin{tabular}{|c|c|c|c|c|c|c|}
\hline \multirow[b]{2}{*}{ Oral finding } & & \multicolumn{2}{|c|}{ DMS IV (2006) } & \multicolumn{2}{|c|}{ DMS V (2016) } & \multirow[b]{2}{*}{$\begin{array}{l}\text { Current study } \\
\text { Post LTx } \\
\text { group: } \\
56 \text { years }\end{array}$} \\
\hline & & $\begin{array}{l}\text { Age } \\
\text { group: } \\
\mathbf{3 5 - 4 4} \\
\text { years }\end{array}$ & $\begin{array}{l}\text { Age } \\
\text { group: } \\
65-74 \\
\text { years }\end{array}$ & $\begin{array}{l}\text { Age } \\
\text { group: } \\
\mathbf{3 5 - 4 4} \\
\text { years }\end{array}$ & $\begin{array}{l}\text { Age } \\
\text { group: } \\
65-74 \\
\text { years }\end{array}$ & \\
\hline DMF-T & & $14.5 \pm 5.7$ & $22.1 \pm 5.9$ & 11.2 & 17.7 & $21.9 \pm 5.4$ \\
\hline D-T & & 0.5 & 0.3 & 0.5 & 0.5 & $0.7 \pm 1.7$ \\
\hline M-T & & 2.4 & 14.1 & 2.1 & 11.1 & $11.4 \pm 8.4$ \\
\hline F-T & & 11.7 & 7.7 & 8.6 & 6.1 & $9.7 \pm 5.8$ \\
\hline \multirow{3}{*}{$\begin{array}{l}\text { Prevalence of } \\
\text { periodontitis }\end{array}$} & No/mild & $27 \%$ & $19 \%$ & $49 \%$ & $35 \%$ & $2.7 \%$ \\
\hline & Moderate & $53 \%$ & $52 \%$ & $43 \%$ & $45 \%$ & $57.5 \%$ \\
\hline & Severe & $20 \%$ & $29 \%$ & $8 \%$ & $20 \%$ & $30.1 \%$ \\
\hline
\end{tabular}

Values are mean \pm standard deviation.

insufficient by $26 \%$ of patients; this would suggest that transplant center and treating physicians need to improve their patient education tools. All of the LTx recipients were seen by a dentist before transplantation and $74 \%$ were treated. In a retrospective study of 102 stem-cell, liver, and heart transplant patients, $80 \%$ of patients who did not complete dental treatment before transplantation had post-operative complications, such as infections and graft rejection, compared with $45.8 \%$ of patients with completed dental treatment. ${ }^{26}$

DMF-T findings for LTx recipients in our study were similar to those for older senior citizens from the general German population in the DMS IV and higher compared with the DMS V. ${ }^{27}$ The DMF-T was nearly identical but the F-T was slightly higher and M-T slightly lower. ${ }^{20}$ When compared with a group of different solid organ transplant recipients with a mean age of 53.9 years ${ }^{18}$ and with the patients after kidney transplantation in a study by Schmalz et al. with a mean age 45.7 years, ${ }^{28}$ our LTx patients had higher DMF-T values which resulted mainly from the high $\mathrm{M}-\mathrm{T}$ values.

The prevalence of periodontal disease in the present study is comparable to that in a study of solid organ transplant recipients: $30.1 \%$ versus $40 \%$ for severe disease, $57.5 \%$ versus $50 \%$ for moderate disease and $2.7 \%$ versus $10 \%$ for mild or no disease. ${ }^{18}$ Differences in values might be explained by the small number of subjects and the screening method employed in the solid organ transplant study.

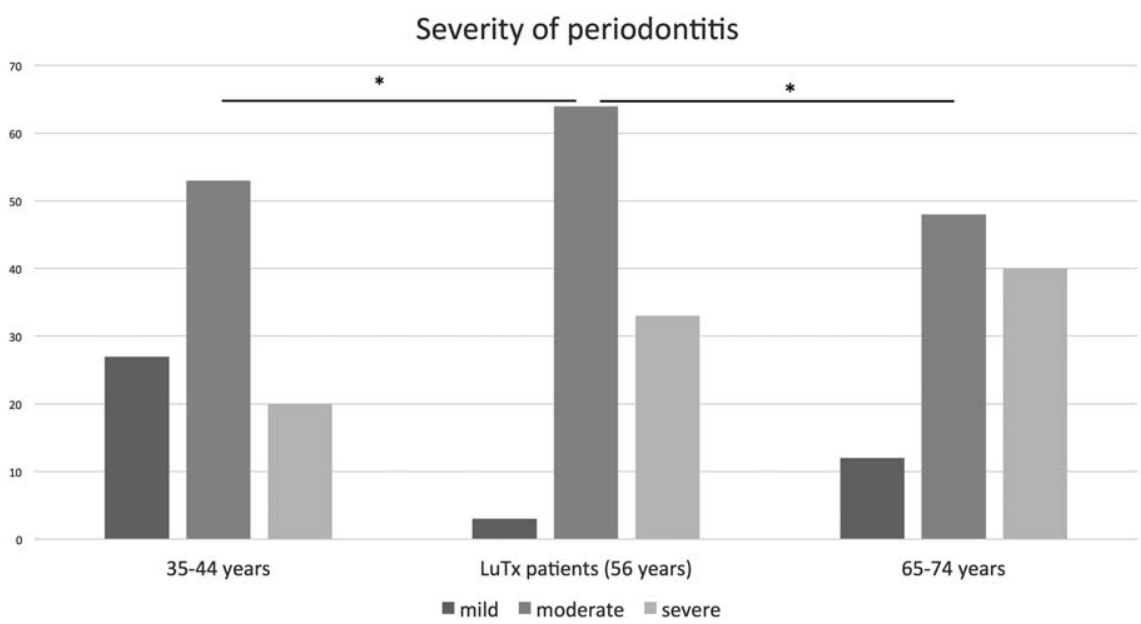

FIGURE 2 Periodontitis severity in toothed lung transplant recipients (LuTx; $n=66)$ compared with adults $(n=904)$ and senior citizens $(n=786)$ of the German general population in the Deutsche Mundgesundheitsstudie IV. ${ }^{20} * P<.05$ for LuTx versus both other subject groups 
Another study with patients after kidney transplantation shows similar outcomes with $32 \%$ severe and $47 \%$ moderate periodontitis, ${ }^{28}$ as well as patients after liver transplantation with $49 \%$ of moderate periodontitis and a lower level of severe periodontitis with $16 \%{ }^{29}$ In renal transplant recipients the prevalence of moderate and severe gingival inflammation receiving tacrolimus was $71.5 \%,{ }^{30}$ compared with a $96.9 \%$ rate of moderate or severe periodontitis in post LTx patients of the present study. Also, it was found a higher prevalence of periodontitis in LTx recipients compared with an older group of the German general population (Figure 2), confirming our original hypothesis. One other study has reported the prevalence of periodontal disease in German LTx candidates in Germany as $57 \%,{ }^{19}$ confirming high levels of periodontal disease in this population. It is possible that the low percentage of reported pre-transplant periodontal treatment $(2.7 \%$ in our study, $2.4 \%$ in the other study) contributed to high levels of post-transplant periodontal disease. These findings are particularly disappointing given that patients showed good adherence to pre-transplant dentist visits, but the focus of these visits seems to be on foci of possible dental infection. This is underlined by the low mean D-T values (i.e., the number of teeth affected by caries) and high numbers of missing (M-T) and filled (F-T) teeth in the patients.

Data on the possible consequences of oral health deficits are scarce. There have been no patient-reported dental infectious foci in the follow-up after lung transplantation, ${ }^{19}$ but there are no large-scale trials looking at infection rates in a larger cohort of recipients with standardized assessment of oral health. Progression of periodontitis depends on the immune response of the host and the existence of risk factors. ${ }^{31}$ Lung transplant recipients need permanent high levels of immunosuppression and therefore have impaired defensive mechanisms against pathogenic bacteria. ${ }^{32}$ However, localized infections might not be the only consequence because periodontal disease has been shown to be associated with systemic disease, such as atherosclerosis. Studies on atherosclerosis and periodontal disease have documented oral bacteria in the coronary plaque, ${ }^{6}$ and elevated levels of pro-inflammatory cytokines. ${ }^{33}$ This combination of danger signals might also influence the occurrence of rejection episodes in lung transplantation. ${ }^{34}$

Therefore, these findings of oral health deficits in LTx recipients are of clinical importance despite a lack of outcome data. After lung transplantation, patients have received maximal medical treatment to enhance their life expectancy and quality of life. Given this very high investment it seems reasonable to make use of any prophylactic measure that might protect the benefits obtained from transplantation. Dental care is easily accessible in most countries and is a scientifically proven way to ensure dental health. Even considering the conflicting data on oral infections (dental and periodontal) in transplant recipients, oral health problems remain a potential negative influence on quality of life and should therefore be prevented.

To the best of our knowledge, this study is the first systematic and standardized examination of oral health, including dental and periodontal health, oral health behavior and oral health awareness in patients after LTx. Although this is the largest study of post-transplant oral health status in LTx recipients, its generalizability might be limited because it was conducted at a single center. This allowed standardized oral examination by a single investigator but there might be center-specific influences. Further prospective multicenter studies could add to knowledge in this area.

Furthermore, it must be considered that this single-center cross-sectional study only represents the actual state of dental and periodontal situation after lung transplantation. The condition before transplantation was only determined by a questionnaire. The patients were examined by their own dentists before transplantation. There was no standardized investigation pre transplant and therefore the pre transplant data of dental treatment could only be evaluated in a questionnaire. Certainly, the data on the patient's basis is faulty. No further check with the respective dentists was performed. Therefore, no assessment can be made of a possible change in the state of the oral health situation (dental and periodontal) from pre to post transplantation.

In conclusion, the results of this study show deficits in oral health and oral health behavior after lung transplantation. Inadequate oral health after transplantation might be the result of a lack of awareness of oral health by transplant recipients and/or insufficient treatment during the pre-transplant examinations. The first step to ensure better oral health is to establish a healthy oral situation before transplantation, which then needs to be preserved after transplantation. Early and ongoing education of patients on the relationship between oral health and transplantation is also needed. The best possible treatment can only be achieved through interdisciplinary collaboration between the transplant team and treating dentists. To facilitate this collaboration there is an unmet need for unified guidelines for the systematic and standardized treatment of patients before and after lung transplantation.

\section{ACKNOWLEDGMENTS}

English language editing assistance was provided by Nicola Ryan, independent medical writer.

\section{CONFLICT OF INTERESTS AND FUNDING SOURCES}

The authors declare that they received no funding for this study and have no competing interests. The results presented in this article have not been published previously in whole or part, except in abstract format. 


\section{ETHICS}

This single-center, cross-sectional study was approved by the ethics committee of the University Hospital Essen (135689-BO) and was registered at the German Clinical Trials Register (DRKS00005746).

\section{AUTHOR CONTRIBUTIONS}

D.D.D. Anna Marcinkowski

D.D.S. Ph.D. Dirk Ziebolz

M.D. Bjoern E. Kleibrink

Ph.D. Gerhard Weinreich

M.D. Ph.D. Markus Kamler

M.D. Ph.D Helmut Teschler

M.D. Urte Sommerwerck

A.M performed clinical examinations and data analysis and wrote the manuscript together with B.E.K, U.S and D.Z.

A.M., U.S., D.Z. and G.W. conceived and designed the study and developed the study protocol. All authors participated in drafting the manuscript, revised it critically for content, and approved its submission. M.K. and H.T. gave input on the study design and supervised the data acquisition.

\section{REFERENCES}

[1] Weill D, Benden C, Corris PA, et al. A consensus document for the selection of lung transplant candidates: 2014-an update from the Pulmonary Transplantation Council of the International Society for Heart and Lung Transplantation. J Heart Lung Transpl. 2015;34: 1-15.

[2] Gottlieb J, Greer M, Sommerwerck U, et al. Introduction of the Lung Allocation Score in Germany. Am J Transplant. 2014;14: 1318-1327.

[3] Yusen RD, Edwards LB, Kucheryavaya AY, et al. The registry of the international society for heart and lung transplantation: thirty-second official adult lung and heartlung transplantation report-2015; focus theme: early graft failure. J Heart Lung Transpl. 2015;34: 1264-1277.

[4] Kotsimbos T, Williams TJ, Anderson GP. Update on lung transplantation: programmes, patients and prospects. Eur Respir Rev. 2012;21: 271-305.

[5] Aas JA, Paster BJ, Stokes LN, Olsen I, Dewhirst FE. Defining the normal bacterial flora of the oral cavity. J Clin Microbiol. 2005;43: 5721-5732.

[6] Cullinan MP, Seymour GJ. Periodontal disease and systemic illness: will the evidence ever be enough?. Periodontol 2000. 2013;62: 271-286.

[7] Otomo-Corgel J, Pucher JJ, Rethman MP, Reynolds MA. State of the science: chronic periodontitis and systemic health. J Evid Based Dent Pract. 2012;12: 20-28.

[8] Socransky SS, Haffajee AD, Cugini MA, Smith C, Kent RL. Microbial complexes in subgingival plaque. J Clin Periodontol. 1998;25: 134-144.
[9] Tomás I, Diz P, Tobías A, Scully C, Donos N. Periodontal health status and bacteraemia from daily oral activities: systematic review/meta-analysis. $J$ Clin Periodontol. 2012;39: 213-228.

[10] Forner L, Larsen T, Kilian M, Holmstrup P. Incidence of bacteremia after chewing, tooth brushing and scaling in individuals with periodontal inflammation. J Clin Periodontol. 2006;33: 401-407.

[11] Wilson W, Taubert KA, Gewitz M, et al. Prevention of infective endocarditis: guidelines from the American Heart Association: a guideline from the American Heart Association Rheumatic Fever, Endocarditis, and Kawasaki Disease Committee, Council on Cardiovascular Disease in the Young, and the Council on Clinical Cardiology, Council on Cardiovascular Surgery and Anesthesia, and the Quality of Care and Outcomes Research Interdisciplinary Working Group. Circulation. 2007;116: 1736-1754.

[12] Paju S, Scannapieco FA. Oral biofilms, periodontitis, and pulmonary infections. Oral Dis. 2007;13: 508-512.

[13] Aguilar-Guisado M, Givaldá J, Ussetti P, et al. Pneumonia after lung transplantation in the RESITRA Cohort: a multicenter prospective study. Am J Transplant. 2007;7: 1989-1996.

[14] Guggenheimer J, Eghtesad B, Stock DJ. Dental management of the (solid) organ transplant patient. Oral Surg Oral Med Oral Pathol Oral Radiol Endod. 2003;95: 383-389.

[15] Guggenheimer J, Eghtesad B, Close JM, Shay C, Fung JJ. Dental health status of liver transplant candidates. Liver Transpl. 2007;13: 280-286.

[16] Kasiske BL, Cangro CB, Hariharan S, et al. The evaluation of renal transplantation candidates: clinical practice guidelines. Am J Transplant. 2001;1Suppl 2: 3-95.

[17] Mehra MR, Kobashigawa J, Starling R, et al. Listing criteria for heart transplantation: international Society for Heart and Lung Transplantation guidelines for the care of cardiac transplant candidates-2006. J Heart Lung Transpl. 2006;25: 1024-1042.

[18] Ziebolz D, Hraský V, Goralczyk A, Hornecker E, Obed A, Mausberg RF. Dental care and oral health in solid organ transplant recipients: a single center cross-sectional study and survey of German transplant centers. Transpl Int. 2011;24: 1179-1188.

[19] Walterspacher S, Fuhrmann C, Germann M, RatkaKrüger P, Windisch W. Dental care before lung transplantation: are we being too rigorous?. Clin Respir J. 2013;7: 220-225.

[20] Institut der Deutschen Zahnärzte. Vierte Deutsche Mundgesundheitsstudie (DMS IV). Köln: Deutscher Zahnärzte Verlag; 2006.

[21] Nusime A, Heide CVD, Hornecker E, Mausberg RF, Ziebolz D. Organtransplantierte und Endoprothesenträger in der zahnärztlichen Praxis. Zur zahnärztlichen Betreuung 
vor bzw. nach Organtransplantation oder Endoprotheseninsertion-eine Befragung von spezifischen Fachzentren. Schweiz Monatsschr Zahnmed. 2011;121: 561-572.

[22] World Health Organisation. Oral Health Survey, Basic Methods. 4th ed. Geneva: World Health Organization; 1997.

[23] Page RC, Eke PI. Case definitions for use in populationbased surveillance of periodontitis. J Periodontol. 2007; 78: $1387-1399$.

[24] National Institute for Health and Care Excellence. Dental recall: recall interval between routine dental examinations. NICE Clinical Guidelines No. 19, London, 2004. 2004.

[25] Velich N, Remport A, Szabó G. Szervtranszplantáción átesett betegek fogászati szúróvizsgálata. Orvosi Hetilap. 2002;143: 505-508.

[26] Melkos AB, Massenkeil G, Neuhaus R, Hummel M, Arnold R, Reiart PA. Organ transplantation: assessment of dental procedures. Quintessenz J. 2005;2: 259-264.

[27] Jordan RA, Michaeelis W. The Fifth German Oral Health Study (DMS V). Köln: Institut der Deutschen Zahnärzte, Deutscher Zahnärzte Verlag; 2016.

[28] Schmalz G, Kauffels A, Kollmar A, et al. Oral behavior, dental, periodontal and microbiological findings in patients undergoing hemodialysis and after kidney transplantation. BMC Oral Health. 2016;1: 72.

[29] Ziebolz D, Schmalz G, Kauffes A, et al. Periodontal pathogenic bacteria and aMMP-8 findings depending on periodontal conditions of patients before and after liver transplantation. Clin Oral Investig. 2016. DOI: 10.1007/ s00784-016-1821-4 [Epub ahead of print].
[30] Pereira-Lopes O, Sampaio-Maia B, Sampaio S, et al. Periodontal inflammation in renal transplant recipients receiving everolimus or tacrolimus - preliminary results. Oral Dis. 2013;19: 666-672.

[31] Beikler T, Karch H, Flemming TF. Mikrobiologische Diagnostik in der Parodontitistherapie: Gemeinsame Stellungnahme der Deutschen Gesellschaft für Parodontologie (DGP) und der Deutschen Gesellschaft für Zahn-, Mund- und Kieferkrankheiten (DGZMK). Deutsche Zahnärztliche Zeitschrift 2005;12: 660-662.

[32] Burguete SR, Maselli DJ, Fernandez JF, Levine SM. Lung transplant infection. Respirology. 2013;18: 22-38.

[33] Paraskevas S, Huizinga JD, Loos BG. A systematic review and meta-analyses on C-reactive protein in relation to periodontitis. J Clin Periodontol. 2008;35: 277-290.

[34] Vos R, Vanaudenaerde BM, De Vleeschauwer SI, et al. Circulating and intrapulmonary C-reactive protein: a predictor of bronchiolitis obliterans syndrome and pulmonary allograft outcome. J Heart Lung Transpl. 2009;28: 799-807.

Please cite this paper as: Marcinkowski A, Ziebolz D, Kleibrink B E, Weinreich G, Kamler M, Teschler H and Sommerwerck U. Deficits in oral health behavior and oral health status in patients after lung transplantation. Clin Respir J 2016; 00: 000-000 DOI:10.1111/ crj.12585. 


\section{Zusammenfassung der Arbeit}

Dissertation zur Erlangung des akademischen Grades Dr. med. dent.

Deficits in oral health behavior and oral health status in patients after lung transplantation

eingereicht von: Anna Marcinkowski

angefertigt an: Poliklinik für Zahnerhaltung und Parodontologie des

Universitätsklinikums Leipzig

betreut von: $\quad$ PD Dr. med. dent. Dirk Ziebolz, M.Sc.

eingereicht: $\quad$ Oktober 2017

LuTx-Patienten zählen zu den Risikopatienten in der zahnärztlichen Praxis und erfordern eine besondere Aufmerksamkeit und Behandlung. Der Mundgesundheitszustand (dental und parodontal) ist ein potentieller Fokus für systemische Erkrankungen. Gerade nach LuTx ist durch die lebenslange und starke Immunsuppression die Anfälligkeit für Infektionen erhöht. Verschiedene Tx-Patientengruppen zeigten insgesamt einen unzureichenden Mundhygienezustand; von LuTx-Patienten liegen bisher keine Daten vor. Demzufolge war das Ziel der vorliegenden Studie einen umfangreichen Überblick über den Mundgesundheitszustand (dental und parodontal) von LuTx-Patienten zu erhalten und das Mundhygieneverhalten sowie das Bewusstsein für die Notwendigkeit einer guten Mundhygiene festzustellen.

Während ambulanter Kontrollen von LuTx-Patienten (mindestens 6 Monate post-Tx), in der Ruhrlandklinik, Westdeutsches Lungenzentrum am Universitätsklinikum Essen, wurden im Rahmen einer klinisch-zahnärztlichen Untersuchung verschiedene Parameter zur Beurteilung des Mundgesundheitszustand erhoben: 
Mundschleimhautbefunde, Zahnstatus (DMF-T) und Parodontalstatus (Sondierungstiefe und Attachmentverlust; Ableitung des Parodontitisschweregrades: mild/gesund, moderat und schwer). Zudem wurde mit standardisierten Fragebögen das Mundgesundheitsverhalten erfasst. In die Studie konnten insgesamt 73 LuTx-Patienten mit einem durchschnittlichen Alter von 55,2 $\pm 9,3$ Jahren und einer durchschnittlichen

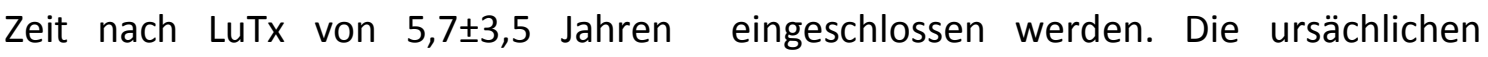
Erkrankungen für die durchgeführte LuTx waren: COPD ( $n=29 ; 21,1 \%)$, ILD ( $n=22 ; 16,1$ $\%), C F(n=5 ; 3,7 \%)$, A1AT-Mangel $(n=10 ; 7,3 \%)$ und andere seltene Erkrankungen $(n=7$; $5,1 \%)$.

Bei der klinischen Untersuchung zeigte sich bei lediglich einem Patienten eine manifestierte Gingivawucherung. Sieben (9,6 \%) Patienten waren zahnlos. Der mittlere DMF-T von 21,9 $\pm 5,4$ weist auf eine ausgeprägte Karieserfahrung dieser Patientengruppe hin; bei einem noch verbesserungsfähigen Kariessanierungsgrad von $91,9 \pm 14,8 \%$. Zwischen den verschiedenen Grunderkrankungen bestand ein signifikanter Unterscheid

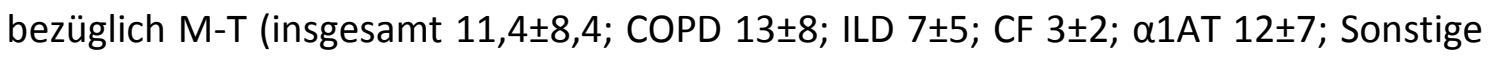
$8 \pm 8 ; p=0,012$ ). Der D-T lag insgesamt bei $0,7 \pm 1,7$ und der F-T bei $9,7 \pm 5,8$; beide Werte unterschieden sich nicht signifikant in den Untergruppen. Die Karieserfahrung (DMF-T) der LuTx Patienten $(21,9 \pm 5,4)$ war vergleichbar mit der älteren Gruppe (65-74 Jahre) der deutschen Allgemeinbevölkerung (Vergleich zur Deutsche Mundgesundheitsstudie; DMS) von 2006 (22,1 $\pm 5,9$; DMS IV), jedoch schlechter im Vergleich zu den Ergebnissen von 2016 (17,7; DMS V). Fast alle bezahnten LuTx Patienten weisen eine moderate (64 \%) oder schwere (33\%) Parodontitis auf. Lediglich 2 Patienten (3\%) hatten gesunde parodontale Verhältnisse. Die Prävalenz moderater Parodontitis der bezahnten LuTxPatienten war im Vergleich zur jüngeren und älteren Gruppe der deutschen Allgemeinbevölkerung (DMS IV) höher (64 \% vs. 53 \% und 48 \%). Zudem war die Prävalenz moderater und schwerer Parodontitis der LuTx-Patienten signifikant höher als die der älteren Gruppe der deutschen Allgemeinbevölkerung.

Die Befragung zum Mundgesundheitsverhalten der LuTx-Patienten zeigte, dass nur knapp dreiviertel der Patienten über den Zusammenhang von Mundgesundheit und TX informiert waren und dies mehrheitlich vom Tx-Zentrum und deutlich seltener vom Zahnarzt ausging. Etwa 20 \% der Patienten war die Notwendigkeit einer AntibiotikaProphylaxe nicht bewusst. Die Mehrheit der untersuchten Patienten (86,3\%) gab an 
regelmäßig einen Zahnarzt aufzusuchen. Vor Transplantation wurden alle Patienten zahnmedizinisch untersucht. Bei knapp dreiviertel von ihnen wurde eine zahnärztliche Behandlung durchgeführt (ohne Spezifizierung). Bei lediglich 2,7 \% der Befragten wurde nach eigenen Feststellungen eine Parodontitis-Behandlung durchgeführt. Fast alle Patienten gaben an sich mindestens einmal am Tag die Zähne zu putzen, aber nur weniger als ein Drittel benutzte Zahnseide oder Interdentalbürstchen als ergänzende Mundhygienehilfsmittel.

Zusammenfassend lässt sich feststellen, dass sich die Prävalenz parodontaler Erkrankungen der LuTx Patienten von der deutschen Allgemeinbevölkerung unterscheidet. Insgesamt liegt ein Verbesserungsbedarf sowohl im Mundgesundheitsverhalten als auch im Mundgesundheitszustand (dental / parodontal) bei Patienten nach LuTx vor. Obwohl der Status Risikopatient ein erhöhtes Mundgesundheitsverhalten erfordert, ist dies hier nicht zu verzeichnen.

Aus den erhobenen Daten dieser Studie lassen sich daher folgende Schlussfolgerungen ziehen:

- Eine Verbesserung des Mundgesundheitszustandes der LuTx-Patienten, besonders vor dem Hintergrund des Status als Risikopatient, ist dringend erforderlich.

- Der Fokus sollte dabei auf Information und Aufklärung der Patienten im besonderen Hinblick auf ihren Status als Risikopatient und der Bedeutung der Mundgesundheit liegen.

- Eine Sensibilisierung der Patienten für ihre eigene Mundgesundheitssituation ist zu erreichen.

- Es besteht die starke Notwendigkeit einer interdisziplinären Zusammenarbeit und der Erstellung verbindlicher klinischer Leitlinien. 


\section{Ausblick}

Für die Risikogruppe transplantierter Patienten (u.a. LuTx) fehlen aktuelle, verbindliche Leitlinien für den sicheren zahnärztlichen Umgang. Für die Erarbeitung dringend notwendiger Leitlinien und Empfehlungen für ein konsequentes zahnmedizinisches Sanierungsprogramm mit Vor- und Nachsorge sollten u.a. die Erkenntnisse aus dieser Untersuchung mit berücksichtigt werden. Patienten nach LuTx weisen im Gegensatz zu anderen Organtransplantierten Besonderheiten auf; einerseits durch die hohe DreifachImmunsuppression und andererseits durch die enge anatomische Beziehung von Mundhöhle und Transplantat. Außerdem muss beachtet werden, dass im Endstadium einer zur LuTx indizierten Lungenerkrankung, die Patienten in ihrem Allgemeinzustand stark geschwächt, nicht mehr belastbar und häufig sauerstoffpflichtig sind. Dementsprechend sollte die zahnärztliche Sanierung bei Lungenerkrankten bereits frühzeitig durchgeführt werden, sodass kurz vor der anstehenden Tx keine umfangreichen und für den Patienten anstrengenden zahnmedizinischen Behandlungen mehr notwendig sind.

Im Rahmen dieser Studie wurde ebenfalls die mundgesundheitsbezogene Lebensqualität (oral health related quality of life, OHRQoL) nach LuTx untersucht und in einer separaten Veröffentlichung der Arbeitsgruppe dargestellt. Dieses zeigt, dass die Wahrnehmung der Mundgesundheit bei Patienten nach LuTx nicht die offensichtlichen Defizite der Mundgesundheit widerspiegelt [43]. Demnach ist eine ausführliche Aufklärung über den Zusammenhang von oralen Erkrankungen und Lungentransplantation sowie intensive Sensibilisierung für eine adäquate Mundhygiene und Motivation dieser Patientengruppe notwendig. 


\section{Literaturverzeichnis}

1. Aguilar-Guisado M, Givaldá J, Ussetti P et al.: Pneumonia after lung transplantation in the RESITRA Cohort: a multicenter prospective study. Am. J. Transplant. 2007;7(8):1989-1996

2. Aimetti M, Romano F, Debernardi C: Effectiveness of periodontal therapy on the severity of cyclosporin A-induced gingival overgrowth. Journal of clinical periodontology 2005;32(8):846-850

3. Baum C, Oldiges M, Oelschner C, Müllerleide K, Klose H, Baumann HJ, Kugler C, Meierling S, Magnussen H, Rabe KF, Deuse T, Reichenspurner H: Norddeutsches Lungentransplantations-Zentrum. Aktuelle Zahlen und erste Erfahrungen mit dem "lung allocation score" (LAS). Hamburger Ärzteblatt 2013;67(1):12-17

4. Biedermann A, Köhnlein T: Alpha-1-Antitrypsin-Mangel - eine Versteckte Ursache der COPD. Überblick über Pathogenese, Diagnostik, Klinik und Therapie. Deutsches Ärzteblatt 2006;103(26):1828-1832

5. Bishay LC, Sawicki GS: Strategies to optimize treatment adherence in adolescent patients with cystic fibrosis. Adolescent health, medicine and therapeutics $2016 ; 7: 117-124$

6. Buell JF, Gross TG, Woodle ES: Malignancy after transplantation. Transplantation 2005;80(2 Suppl):S254-264

7. Costabel U: Interstitielle Lungenerkrankungen. Fortschritte in den letzten 10 Jahren und Perspektiven für die weitere Entwicklung. Der Pneumologe 2013;(Supplement 1):47-52

8. Cullinan MP, Seymour GJ: Periodontal disease and systemic illness: will the evidence ever be enough? Periodontology 2000 2013;62(1):271-286

9. Dongari-Bagtzoglou A, Dwivedi P, loannidou E, Shaqman $M$, Hull D, Burleson J: Oral Candida infection and colonization in solid organ transplant recipients. Oral microbiology and immunology 2009;24(3):249-254 
10. Estenne M, Maurer JR, Boehler A et al.: Bronchiolitis obliterans syndrome 2001: an update of the diagnostic criteria. The Journal of Heart and Lung Transplantation 2002;21(3):297-310

11. Eurotransplant International Foundation: Statistic report. Waiting list mortality in Germany, by year, by organ.

http://statistics.eurotransplant.org/reportloader.php?report=57324-

6010\&format=html\&download=0

12. Eurotransplant International Foundation: Statistic Report. Active lung waiting list (at year-end) in Germany, by year, by organ combination.

http://statistics.eurotransplant.org/reportloader.php?report=56816-6010-

6144\&format=html\&download=0

13. Eurotransplant International Foundation: Statistic Report. Lung transplants in Germany, by year, by donor type, by organ combination.

http://statistics.eurotransplant.org/reportloader.php?report=55913-6010-

6144\&format=html\&download=0

14. Forner L, Larsen T, Kilian M, Holmstrup P: Incidence of bacteremia after chewing, tooth brushing and scaling in individuals with periodontal inflammation. Journal of clinical periodontology 2006;33(6):401-407

15. Guggenheimer J, Eghtesad B, Close JM, Shay C, Fung JJ: Dental health status of liver transplant candidates. Liver Transpl 2007;13(2):280-286

16. Guggenheimer J, Eghtesad B, Stock DJ: Dental management of the (solid) organ transplant patient. Oral surgery, oral medicine, oral pathology, oral radiology, and endodontics 2003;95(4):383-389

17. Hartert M, Senbaklavacin O, Gohrbandt B, Fischer BM, Buhl R, Vahld C: Lung transplantation: a treatment option in end-stage lung disease. Deutsches Arzteblatt international 2014;111(7):107-116

18. Hemmert $C$, Ohana $M$, Jeung $M$ et al.: Imaging of lung transplant complications. Diagnostic and interventional imaging 2014;95(4):399-409 
19. Irani S, Schmidlin PR, Bolivar I, Speich R, Boehler A: Evidence for graft colonization with periodontal pathogens in lung transplant recipients. A pilot study. Schweiz Monatsschr Zahnmed 2011;121(12):1144-1149

20. ISHLT: Lung Transplantation. Adult Recipients. Adult Lung Transplants - Indiktions (1995-2015). JHLT;2016 Oct; 35 (10):1149-1205

21. Jordan RA, Bodechtel C, Hertrampf K et al.: The Fifth German Oral Health Study (Fünfte Deutsche Mundgesundheitsstudie, DMS V) - rationale, design, and methods. Köln: Instuitut der Deutchen Zahnärzte. BMC oral health 2014;14:161

22. Kasiske BL, Cangro CB, Hariharan $\mathrm{S}$ et al.: The evaluation of renal transplantation candidates: clinical practice guidelines. American journal of transplantation : official journal of the American Society of Transplantation and the American Society of Transplant Surgeons 2001;1 Suppl 2:3-95

23. Kauffels A, Schmalz G, Kollmar O et al.: Oral findings and dental behavior before and after liver transplantation - a single-center cross-sectional study. International dental journal 2017

24. Khoori AH, Einollahi B, Ansari G, Moozeh MB: The effect of cyclosporine with and without nifedipine on gingival overgrowth in renal transplant patients. J Can Dent Assoc 2003;69(4):236-241

25. Kotloff RM, Thabut G: Lung Transplantation. Am J Respir Crit Care Med 2011;184(2):159-171

26. Kotsimbos T, Williams TJ, Anderson GP: Update on lung transplantation: programmes, patients and prospects. European respiratory review : an official journal of the European Respiratory Society 2012;21(126):271-305

27. Little JW, Falace DA, Mühlenbein F, Linker H: Zahnärztliche Behandlung von Risikopatienten. (Deutsche Übersetzung von Mühlenbein und Linker). Deutscher Ärzte-Verlag, Köln 1991

28. Lynch JP, Sayah DM, Belperio JA, Weigt SS: Lung transplantation for cystic fibrosis: results, indications, complications, and controversies. Seminars in respiratory and critical care medicine 2015;36(2):299-320 
29. Mehra MR, Kobashigawa J, Starling R et al.: Listing criteria for heart transplantation: International Society for Heart and Lung Transplantation guidelines for the care of cardiac transplant candidates--2006. The Journal of heart and lung transplantation : the official publication of the International Society for Heart Transplantation 2006;25(9):1024-1042

30. Melkos AB, Massenkeil G, Neuhaus R, Hummel M, Arnold R, Reiart PA: Organ Transplantation. - Assessment of Dental Procederes. Quintessenz Journals 2005:4: 249-264

31. Naber CK, Al-Nawas B, Baumgartner H, Becker H-J, Block M, Erbel R: Prophylaxe der infektiösen Endokarditis. Positionspapier. Kardiologe;2007:1:243-250

32. National Institute for Health and Care Excellence: NICE clinical guideline 19. Recall interval between routine dental examinations. https://www.nice.org.uk/guidance/cg19

33. Ng CY, Madsen JC, Rosengard BR, Allan JS: Immunosuppression for lung transplantation. Frontiers in bioscience (Landmark edition) 2009;14:1627-1641

34. Nusime A, Heide, Clarissa V D, Hornecker E, Mausberg RF, Ziebolz D: Organtransplantierte und Endoprothesenträger in der zahnärztlichen Praxis. Zur zahnärztlichen Betreuung vor bzw. nach Organtransplantation oder Endoprotheseninsertion--eine Befragung von spezifischen Fachzentren. Schweiz Monatsschr Zahnmed 2011;121(6):561-572

35. Otomo-Corgel J, Pucher JJ, Rethman MP, Reynolds MA: State of the science: chronic periodontitis and systemic health. The journal of evidence-based dental practice 2012;12(3 Suppl):20-28

36. Otten J.-E.: Wissenschaftliche Stellungsnahme der Deutschen Gesellschaft für Zahn Mund und Kieferheilkunde (DGZMK). Zahnsanierung vor und nach Organtransplantation. DZZ 54 (99) 1998

37. Paju S, Scannapieco FA: Oral biofilms, periodontitis, and pulmonary infections. Oral diseases 2007;13(6):508-512 
38. Penninga L, Penninga El, Møller CH, Iversen M, Steinbrüchel DA, Gluud C: Tacrolimus versus cyclosporin as primary immunosuppression for lung transplant recipients. Cochrane Database Syst Rev 2013;5:CD008817

39. Pereira-Lopes O, Sampaio-Maia B, Sampaio S et al.: Periodontal inflammation in renal transplant recipients receiving everolimus or tacrolimus - preliminary results. Oral diseases 2013;19(7):666-672

40. Pham PT, Pham PT, Lipshutz GS, Wilkinson AH: New onset diabetes mellitus after solid organ transplantation. Endocrinology and metabolism clinics of North America 2007;36(4):873-90; vii

41. Rustemeyer J, Bremerich A: Necessity of surgical dental foci treatment prior to organ transplantation and heart valve replacement. Clin Oral Invest 2007;11(2):171-174

42. Schmalz G, Kauffels A, Kollmar O et al.: Oral behavior, dental, periodontal and microbiological findings in patients undergoing hemodialysis and after kidney transplantation. BMC oral health 2016;16(1):72

43. Schmalz G, Wendorff $H$, Marcinkowski A et al.: Oral health related quality of life depending on oral health and specific factors in patients after lung transplantation. The Clinical Respiratory Journal;2017

44. Schmalz G, Ziebolz D: Patienten vor und nach Organtransplantation - Eine Herausforderung für das Praxisteam. Prophylaxe Journal;2016(3)

45. Schmickler J, Widmer F, Kauffels A, Kollmar O, Mausberg RF, Ziebolz D.: Mundgesundheitszustand und zahnärztlicher Behandlungsbedarf von organtransplantierten Patienten. Deutsche Zahnärztliche Zeitschrift 2016:71:114123

46. Schrem H, Barg-Hock H, Strassburg CP, Schwarz A, Klempnauer J: Nachsorge bei Organtranplantation. Deutsches Ärzteblatt 2009;106(9):148-156

47. Sommerwerck U, Rabis T, Fleimisch P, Carstens $H$, Teschler H, Kamler M: Lungentransplantation. Herz 2014;39(1):74-83 
48. Strüber M, Reichenspurner H: Die Einführung des Lungenallokations-Scores für die Lungentransplantation in Deutschland. Deutsches Ärzteblatt 2011;108(45):24242442

49. Tomás I, Diz P, Tobías A, Scully C, Donos N: Periodontal health status and bacteraemia from daily oral activities: systematic review/meta-analysis. Journal of clinical periodontology 2012;39(3):213-228

50. Velich N, Remport A, Szabó G: Szervtranszplantáción átesett betegek fogászati szúróvizsgálata. Orvosi hetilap 2002;143(10):505-508

51. Voshaar T, Köhler D, Schönhofer B: Pneumologie. Ein Leitfaden für rationales Handeln in Klinik und Praxis ; 36 Tabellen. THIEME, Stuttgart, New York, NY 2010

52. Walterspacher S, Fuhrmann C, Germann M, Ratka-Krüger P, Windisch W: Dental care before lung transplantation: are we being too rigorous? The Clinical Respiratory Journal 2013;7(2):220-225

53. Wilson W, Taubert KA, Gewitz M et al.: Prevention of infective endocarditis: guidelines from the American Heart Association: a guideline from the American Heart Association Rheumatic Fever, Endocarditis, and Kawasaki Disease Committee, Council on Cardiovascular Disease in the Young, and the Council on Clinical Cardiology, Council on Cardiovascular Surgery and Anesthesia, and the Quality of Care and Outcomes Research Interdisciplinary Working Group. Circulation 2007;116(15):1736-1754

54. Yusen RD, Edwards LB, Kucheryavaya AY et al.: The Registry of the International Society for Heart and Lung Transplantation: Thirty-second Official Adult Lung and Heart-Lung Transplantation Report--2015; Focus Theme: Early Graft Failure. The Journal of heart and lung transplantation : the official publication of the International Society for Heart Transplantation 2015;34(10):1264-1277

55. Ziebolz D, Hraský V, Goralczyk A, Hornecker E, Obed A, Mausberg RF: Dental care and oral health in solid organ transplant recipients: a single center cross-sectional study and survey of German transplant centers. Transpl. Int. 2011;24(12):11791188 
56. Ziebolz D: Der infektionsgefährdete Patient - was der Zahnarzt wissen sollte. ZWP Spezial;2009; 10:(Supplement 3): 8-12

57. Zwiech R, Bruzda-Zwiech A: Does oral health contribute to post-transplant complications in kidney allograft recipients? Acta odontologica Scandinavica $2013 ; 71(3-4): 756-763$ 


\section{Wissenschaftliche Präsentationen}

Anna Marcinkowski, Björn Kleibrink, Gerhard Weinreich, Markus Kamler, Helmut Teschler, Dirk Ziebolz, Urte Sommerwerck

Mundgesundheitszustand bei Patienten nach Lungentransplantation - erste Ergebnisse einer klinisch monozentrischen Querschnittsstudie

56. Kongress der Deutschen Gesellschaft für Pneumologie und Beatmungsmedizin e.V. (DGP), 18. - 21.03.2015, Berlin 


\section{Darstellung des eigenen Beitrags}

\section{Erklärung über den wissenschaftlichen Beitrag des Promovenden zur Publikation}

Name, Vorname:

Marcinkowski, Anna

Institut:

Poliklinik für Zahnerhaltung und Parodontologie

Angestrebter Doktorgrad: Dr. med. dent.

Thema der Dissertation: Deficits in oral health behavior and oral health status in patients after lung transplantation

Hiermit erkläre ich, dass ich bei der Erstellung und Veröffentlichung der Publikation:

Marcinkowski A, Ziebolz D, Kleibrink B.E, Weinreich G, Kamler M, Teschler H, Sommerwerck U

Deficits in oral health behavior and oral health status in patients after lung transplantation

Clinical Respiratory Journal. 2016 Nov 18. doi: 10.1111/crj.12585. [Epub ahead of print]

folgenden wissenschaftlichen Beitrag geleistet habe:

- $\quad$ Administrative Vorbereitung und Organisation der klinischen Studie

- Ausarbeitung des Studienprotokolls zur Beurteilung des Forschungsvorhabens durch die Ethik-Kommission

- Zahnärztliche Untersuchung der Studienteilnehmer

- Datenerfassung und Aufbereitung für die statistische Auswertung

- Interpretation der Ergebnisse

- $\quad$ Erstellung des Manuskripts

\section{Miheim 2608.17}

Ort, Datum

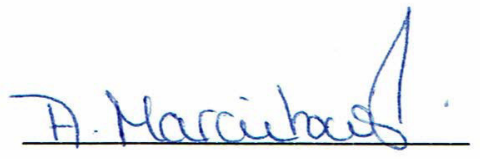

Anna Marcinkowski 
Hiermit bestätige ich als Mitautor o.g. Publikation die von Frau Anna Marcinkowski abgegebene Erklärung:

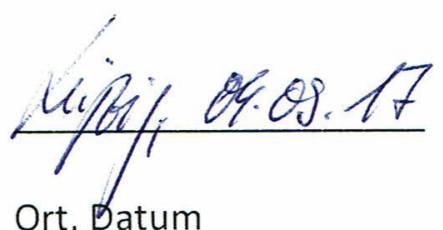

Ort, Batum

Essen, 27.8 .17

Ort, Datum

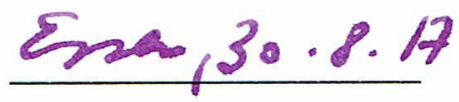

Ort, Datum

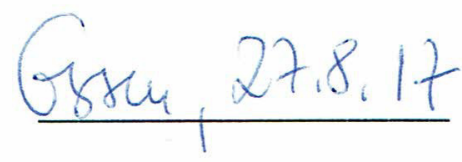

Ort, Datum
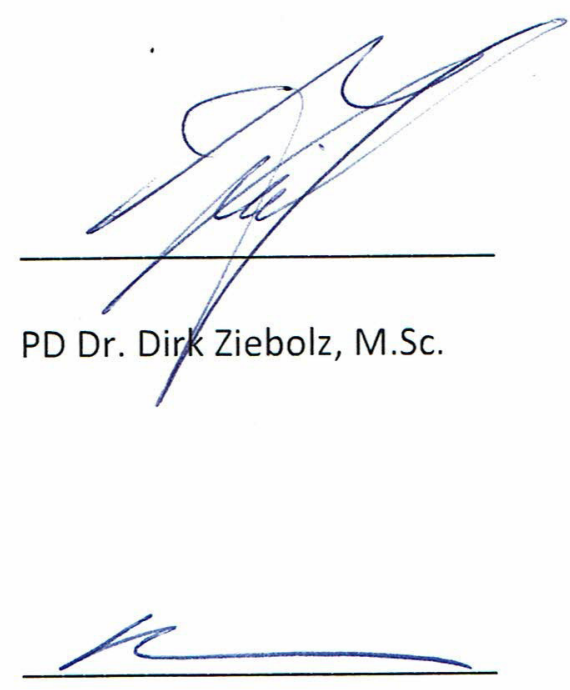

Dr. Björn E. Kleibrink

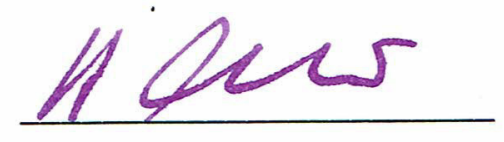

Prof. Dr. Helmut Teschler

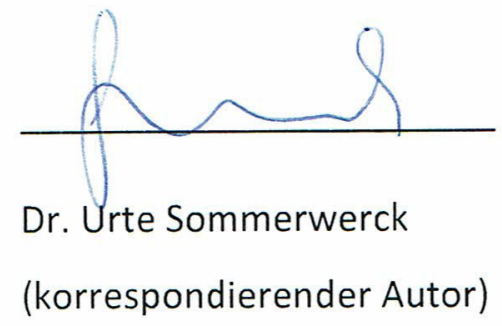




\section{Erklärung über die eigenständige Abfassung der Arbeit}

Hiermit erkläre ich, dass ich die vorliegende Arbeit selbstständig und ohne unzulässige Hilfe oder Benutzung anderer als der angegebenen Hilfsmittel angefertigt habe. Ich versichere, dass Dritte von mir weder unmittelbar noch mittelbar eine Vergütung oder geldwerte Leistungen für Arbeiten erhalten haben, die im Zusammenhang mit dem Inhalt der vorgelegten Dissertation stehen, und dass die vorgelegte Arbeit weder im Inland noch im Ausland in gleicher oder ähnlicher Form einer anderen Prüfungsbehörde zum Zweck einer Promotion oder eines anderen Prüfungsverfahrens vorgelegt wurde. Alles aus anderen Quellen und von anderen Personen übernommene Material, das in der Arbeit verwendet wurde oder auf das direkt Bezug genommen wird, wurde als solches kenntlich gemacht. Insbesondere wurden alle Personen genannt, die direkt an der Entstehung der vorliegenden Arbeit beteiligt waren. Die aktuellen gesetzlichen Vorgaben in Bezug auf die Zulassung der klinischen Studien, die Bestimmungen des Tierschutzgesetzes, die Bestimmungen des Gentechnikgesetzes und die allgemeinen Datenschutzbestimmungen wurden eingehalten. Ich versichere, dass ich die Regelungen der Satzung der Universität Leipzig zur Sicherung guter wissenschaftlicher Praxis kenne und eingehalten habe.

\section{Heilheim 14.10. A}

Ort, Datum

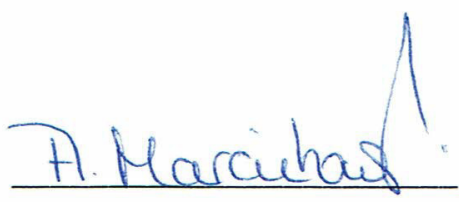

Anna Marcinkowski 


\section{Lebenslauf}

\section{Anna Marcinkowski}

\section{Persönliche Daten}

Geboren: 27. April 1988 in Essen

Staatsangehörigkeit: deutsch

Adresse privat: $\quad$ Oberstraße 20 in 45468 Mülheim an der Ruhr

E-Mail: anna.marcinkowski@gmx.de

Schulausbildung, Studium und beruflicher Werdegang

$08.1994-07.1998$ Besuch der Grundschule; Stiftschule in Essen

08.1998-07.2004 Erwerb der Fachoberschulreife; Albert-Einstein-Realschule in Essen

08.2004-01.2007 Ausbildung zur Zahnmedizinische Fachangestellte (ZMF); Praxis Werner Jochheim in Essen; Abschlussnote: sehr gut

01.2007 Erhalt der Begabtenförderung „Beruflich Bildung“ der Zahnärztekammer Nordrhein

02.2007-12.2009 Erwerb der Allgemeinen Hochschulreife; Ruhrkolleg in Essen Leistungskurse: Mathematik / Geschichte; Abschlussnote: 2,3

01.2010 - 03.2010 Berufstätigkeit als Zahnmedizinische Fachangestellte; Praxis Werner Jochheim in Essen

04.2010 - 06.2015 Studium der Zahnmedizin; Georg-August-Universität in Göttingen Approbation zur Zahnärztin am 05.08.2015 Naturwissenschaftliche Vorprüfung: sehr gut Zahnärztliche Vorprüfung: gut Zahnärztliche Prüfung: sehr gut

07.2015 Erhalt des „Alex-Motsch-Studentenpreises“

ab 11.2015 Assistenzzahnärztin; Fachzahnarztpraxis für Oralchirurgie Dr. Lars Lansnicker in Mülheim an der Ruhr 


\section{Danksagung}

Ich möchte mich bei meinem Doktorvater Herrn PD Dr. Dirk Ziebolz bedanken für die Möglichkeit, unter seiner hervorragenden Betreuung promovieren und die vorliegende Arbeit erstellen zu dürfen.

Ebenfalls bedanke ich mich ganz besonders bei Frau Dr. Urte Sommerwerck und dem Team der Ruhrlandklink dafür, dass diese Studie überhaupt praktisch umgesetzt werden konnte und für die wunderbare Zusammenarbeit in den letzten Jahren.

Selbstverständlich danke ich auch allen Mitautoren des zu dieser Arbeit gehörenden Manuskripts, durch die diese Veröffentlichung erst möglich wurde. Hervorheben möchte ich an dieser Stelle Herrn Dr. Björn Kleibrink - Danke für jeglichen Rat.

Meinen Eltern und Geschwistern danke ich für ihre bedingungslose Unterstützung und die Gabe mich immer wieder aufs Neue zu motivieren. 